\title{
Vertebrate paleontology in Brazil - a review
}

1. Dept. Geology and Paleontology, Museu Nacional/UFRJ, Quinta da Boa Vista, São Cristóvão, Rio de Janeiro, Brazil; e-mail: kellner@acd.ufrj.br 2. Museu de Ciências da Terra, DNPM, Av. Pasteur 404, Rio de Janeiro, Brazil; e-mail: dac@abc.org.br

A review of the vertebrate fossil diversity in Brazil is presented. The best known faunas are the fish and reptiles from the Santana Formation (both, Crato and Romualdo Members). Also comparatively well known are the mammalian faunas from Pleistocene deposits, which is the result of extensive research done in the last decades. Poorly known are the Paleozoic vertebrates, which is possible due to the limited outcrops in the country. Paradoxically, the Late Cretaceous vertebrate faunas (fishes, reptiles, and mammals) from the Bauru Group are also poorly known, despite the large extension of these sedimentary rocks in the country. Following the achievements in the last decades, continuous systematic fieldwork has to be done, with the employment of various collecting techniques (e.g., screen washing), in order to improve the knowledge about the Brazilian paleovertebrate faunas.

\section{Introduction}

Fossil vertebrates are known in Brazil since the last century (1820's), when two German naturalist, Johann Baptist von Spix and Karl Friedrich Philipp von Martius mentioned the fossil deposit that is now known as the Santana Formation. Those authors also figured a small fish* (Spix and Martius, 1823 -1831) preserved in a calcareous nodule from those strata (Romualdo Member), which, along with a Pleistocene mammal, was the first fossil from this country to be illustrated (Kellner, 1989).

Still in the last century, other researchers studied Brazilian fossil remains. Among them was Peter Wilhelm Lund, who described several Pleistocene mammals from limestone caves of Minas Gerais (Cartelle, 1994). However, only starting in the thirties of the present century, vertebrate paleontology started to be developed in this country, with the studies done by Friedrich von Huene, Mathias Gonçalves de Oliveira Roxo, Llewellyn Ivor Price, Carlos de Paula Couto, and Rubens da Silva Santos (for a short review see Mendes, 1974; Ramos, 1985).

In the present paper we present a brief review of the most important fossil deposits of Brazil. Fossil Lagerstätten are presented in the geologic sequence in which they were formed (e.g., older deposit first) and the most common or significant taxa are emphasized, particularly the amniotes (Figures 1,2).

\section{Devonian vertebrates}

The record of Paleozoic vertebrates in Brazil is extremely scarce. With the exception of the specimens found in Permian layers (discussed elsewhere) and the description of a Late Devonian tetra-

*In this paper we use the term "fish" in the popular sense, meaning all non-tetrapod vertebrates. pod footprint from the Paraná Basin (Leonardi, 1983), vertebrate remains from this era have only been briefly mentioned in faunal lists from Devonian strata (e.g., Katzer, 1897a, b; Kegel, 1953, 1957; Santos, 1961; Mendes and Petri, 1971; Copper, 1977).

In the last two decades some isolated Paleozoic specimens were described in detail. Among those are isolated actinopterygian scales found in drilling cores of an oil well in the Upper Amazon Basin, Northwestern Brazil (Janvier and Melo, 1987). These scales are preserved in black shales and suggest either a very Late Devonian or a Carboniferous age for those sediments, although the associated microfossils favor a pre-Mississippian assignment (Janvier and Melo, 1987). Those authors also reported acanthodian remains from Devonian strata of the same basin (Janvier and Melo, 1988; 1992).

\section{Irati Formation (Permian, Paraná Basin)}

The Irati Formation is regarded by several authors to represent a restricted sea. The deeper portions are made of a succession of shales and mudstones, locally bituminous that were deposited in an offshore environment where anoxic condition predominated. The shallower areas are represented by limestones and dolomites (Figure 2a) and were deposited nearshore (Oelofsen and Araújo, 1983). In some parts coarser clastic carbonatic layers with wavy laminations and hummocky cross stratifications can also be found, that are considered as evidences of large Permian storms (Lavina et al., 1991). Those strata have been traditionally dated as Kazanian (Barberena et al., 1985) but palynological data suggest a Tatarian (Upper Permian) age (vide Lavina et al., 1995).

The most common fossils of this unit are basal amniotes classified in the Mesosauridae (Figure 3), which are known from several localities in the states of Rio Grande do Sul (Passo de São Borja), Paraná (São Mateus), São Paulo (Rio Claro), and Goiás (see Araújo, 1976). Those lizard-like animals are represented by three taxa, Mesosaurus, Stereosternum, and Brazilosaurus that are distinguished from each other by the length of the skull, cervical vertebrae, and features of the teeth and haemal arches (Oelofsen and Araújo, 1983; 1987). Remains of those fossils were also found in South Africa, Uruguay, and Paraguay, indicating a close paleobiogeographic connection between the Southern part of South America and Africa during the Late Permian.

Although rarer, fish remains are found too, particularly elasmobranchs, paleoniscids, and occasionally scales of coelacanthids (Richter, 1985).

\section{Pedra do Fogo Formation (Permian, Parnaíba Basin)}

The Pedra do Fogo Formation is composed of siltstones, shales, and limestones that are very rich in chert and silicified wood (Psaronius). Those strata were deposited in lagoonal and fluvial environments, with locally some eolian and marine influence (Schobbenhaus et al., 1984). Based on palynomorphs, the age of those strata is regarded as Early Permian. 


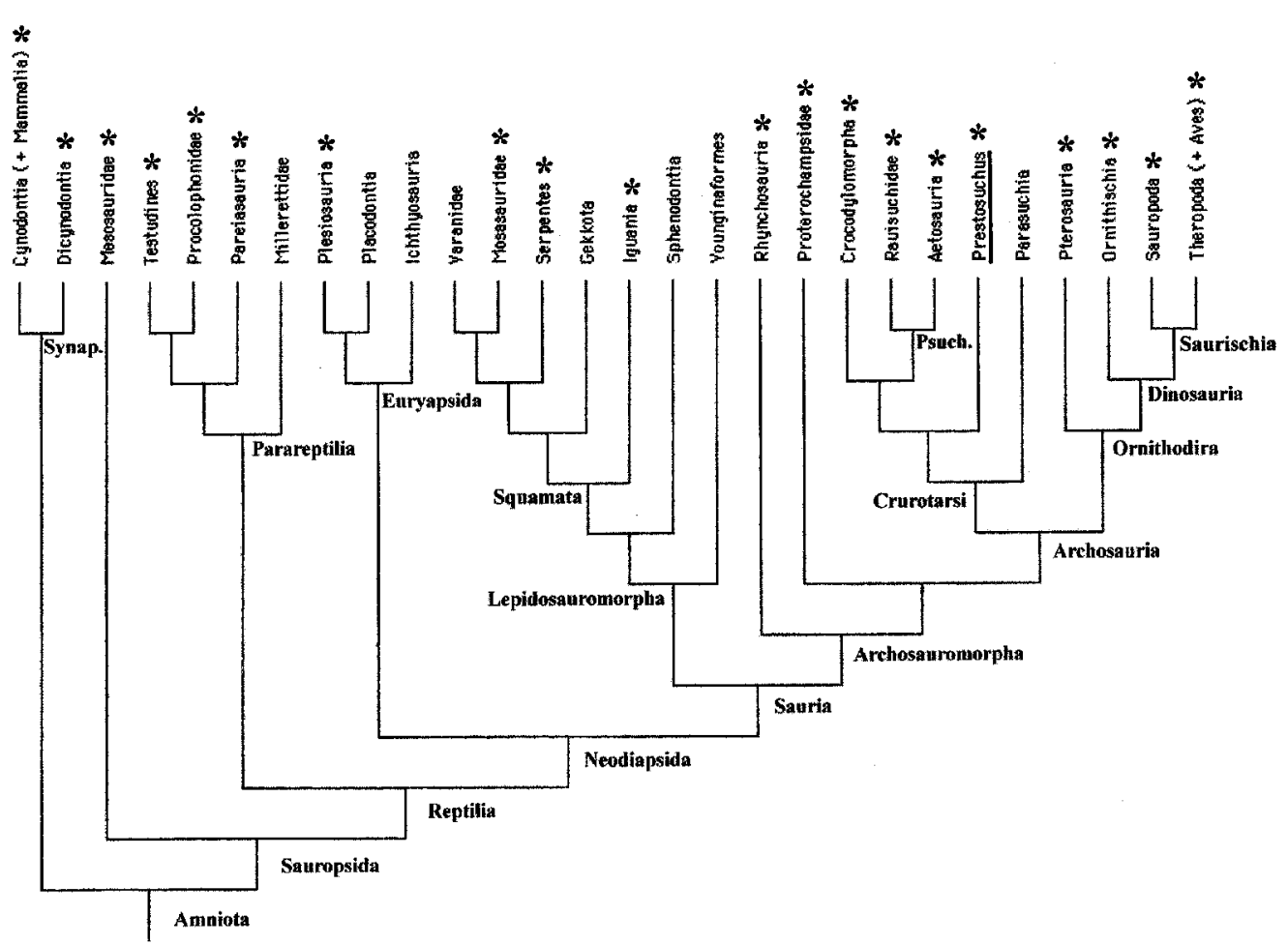

paratively rare and very fragmentary, but procolophonid reptiles have been found (Lavina, 1983), some are still undescribed (Silva, 1997). Recently remains of synapsids (Dicynodontia) have also been reported (Schwanke and Kellner, 1999). Several fragments of amphibian and some other primitive reptiles are known too, but most have not been studied so far. To our knowledge, no fish remains have been reported from this unit.

\section{Santa Maria Formation (Middle- Late Triassic, Paraná Basin)}

The Santa Maria Formation is the richest Brazilian fossil deposit of Triassic age. Composed of siltstones and pelitic sediments that were formed mainly in fluvial and lacustrine environments (Figure

Figure 1 Cladogram showing the phylogenetical relationships of the main groups of Amniota, with emphasis on the Reptilia (from Kellner, 1998). Groups recorded in Brazil are marked (*). Note that the record of Ornithischia is only based on ichnofossils. Abbreviations: Synap.: Synapsida; Psuch.: Pseudosuchia.

Among the vertebrate fossils, the most common are fish remains such as elasmobranchs, paleoniscids, and lungfishes (Dipnoi). The only tetrapod recorded so far is the long-snouted amphibian Prionosuchus, described by Price (1948).

This stratigraphic unit that outcrops in the Northeastern Brazil has not been very much prospected, despite its potential for continental fossil vertebrates of Permian age, particularly amphibians.

\section{Continental Permo-Triassic of the Paraná Basin}

So far, outcrops of former continental environments showing the passage between the Permian and the Early Triassic are only found in the southern part of Brazil. This passage is represented by two stratigraphic units that are presently regarded as part of the same stratigraphic sequence: Rio do Rasto and Sanga do Cabral Formations (Faccini et al., 1995).

The Rio do Rasto Formation is essentially composed of siltstones and sandstones, which were deposited under fluvial conditions during the Late Permian (Tatarian), and outcrop in the states of Rio Grande do Sul and Paraná (Barberena et al., 1985). These sediments are quite interesting since they preserve an important fauna of amphibians, which was only partially studied (Barberena, 1998; Barberena and Dias, 1998). Furthermore, the Rio do Rasto Formation shows the presence of a synapsid dicynodont (Barberena et al., 1985) and has yielded the only Brazilian pareiasaur (primitive group of reptiles) taxon know to date, the latter being represented by three specimens (Araújo, 1985). Other than the fossils mentioned above, those strata have furnished some fish remains, particularly isolated material of chondrichthyans and paleoniscids.

The Sanga do Cabral Formation is mainly composed of red sandstones (Andreis et al., 1980) that have an Early Triassic (Scythian) age (Faccini et al., 1995). Fossil in those strata are com-
$2 \mathrm{~b}$ ), the age of those rocks ranges from Middle to Late Triassic (Ladinian - Norian; Faccini et al., 1995). The fossils from this stratigraphic unit are known since the beginning of this century. Between 1928 and 1929, extensive collecting in those strata was done by the German paleontologist Friedrich von Huene, who published a classic work (Huene, 1942) that was used for several years as the basic paleontological textbook about this fossil deposit. More recently research in those continental strata was intensified and several new fossils were found (see Kellner, 1998, for a review).

Among the most abundant fossils of the Santa Maria Formations are synapsids, particularly dicynodonts. These vertebrates, once erroneously regarded as reptiles (= "mammal-like reptiles" (e.g., see Gauthier et al., 1988; Kellner, 1998) are particularly common on the basal and top layers of this stratigraphic unit. So far some hundred individuals of this group have been found and were classified into six different taxa (Schwanke, 1995). Being the first largest herbivore group of the Mesozoic, morpho-functional studies were performed, suggesting that some dicynodonts were feeding on specific vegetation, forming a co-evolutive pair (Schwanke, 1998).

Other important synapsids found in the Santa Maria Formation are primitive cynodonts. Although less common, cynodonts are of particular interest because some are closely related to modern mammals, such as Therioherpeton (Bonaparte and Barberena, 1987). So far there are about ten cynodont taxa described from those layers, comprising carnivorous, herbivorous, and omnivorous forms. More recently several new specimens have been found that are being presently studied (Bonaparte, personal communication 1998).

Among the fossil reptiles, the most common belong to a primitive group of archosauromorphs (Reptilia) know as rhynchosaurs (Figures 1, 2b). Their remains are particularly abundant in the middle section of the Santa Maria Formation, where the climate is regarded to have been comparatively drier (Azevedo et al., 1990). So far only two taxa are considered valid, but more have been presented (Langer and Schultz, 1997).

Other reptiles represented in the Santa Maria Formation are procolophonids (Price, 1947), proterochampsids (Barberena, 1982), rauisuchids (Huene, 1942), crocodylomorphs (Mattar, 1987), fragmentary remains of aetosaurs (Barberena et al., 1985), and some other primitive archosaurs like Prestosuchus (see Kellner, 1998, for a review). Dinosaur remains have bee found too, but are very rare 

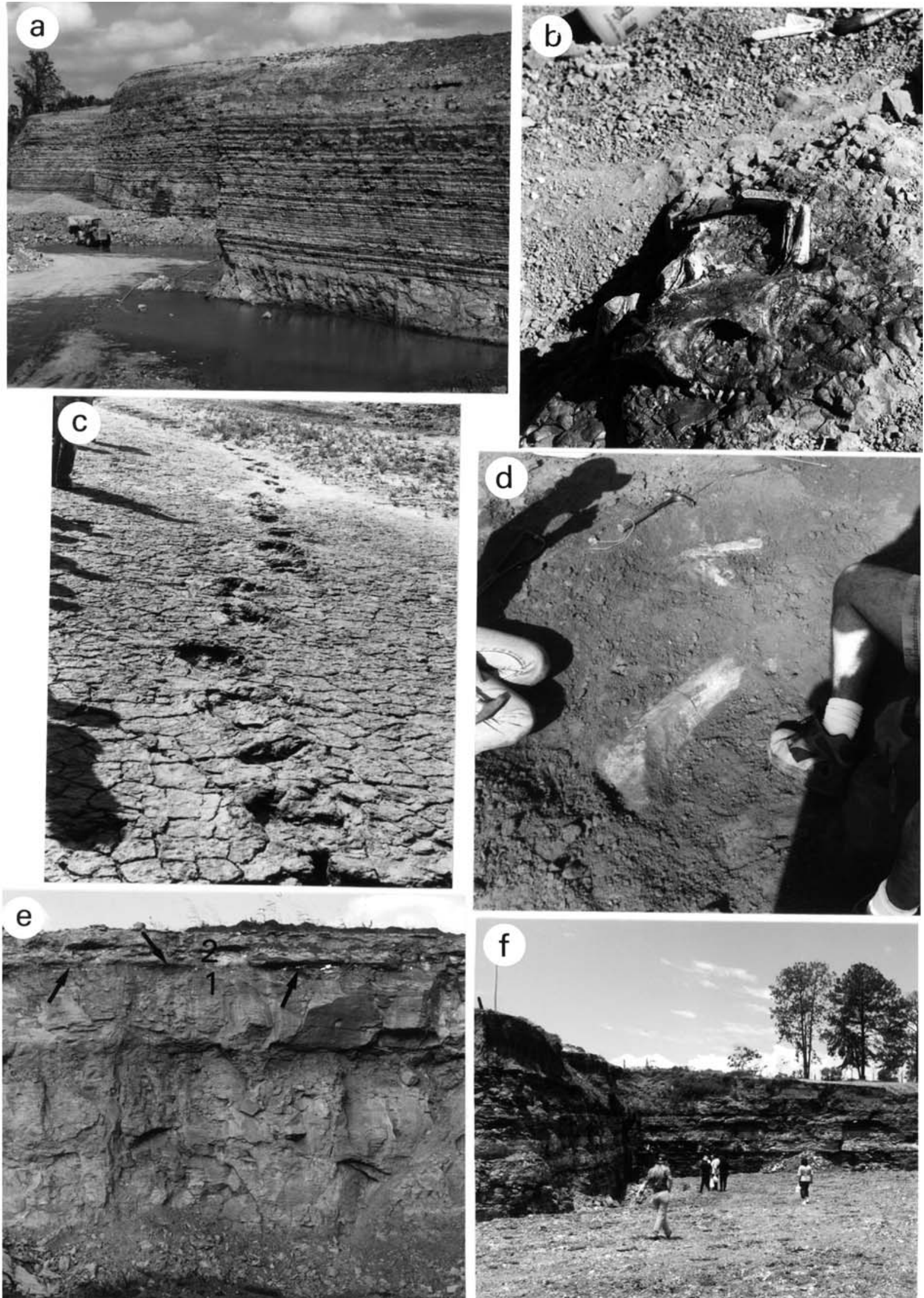

Figure 2 Main fossil deposits in Brazil: a - Irati Formation (Permian), in São Paulo State; b - outcrop of the Santa Maria Formation (Triassic), Rio Grande do Sul State, showing the skull of a rhynchosaur (Archosauromorpha, Reptilia); $c$ - dinosaur trackway preserved near the town of Sousa (Early Cretaceous), Paraiba State; $d$-dinosaur bones found the Bauru Group (Late Cretaceous) at Prata, Minas Gerais State; $e$ - outcrop showing the K/T boundary (arrows) between the Gramame (1 - lower unit, Maastrichtian) and Maria Farinha (2 - upper unit, Paleocene) formations, in Pernambuco; $f$ - The outcrops of Tremembé Formation (Oligo-Miocene), Taubaté Basin. 
and belong to one primitive theropod, Staurikosaurus (Colbert, 1970) and to undescribed prosauropods.

The Santa Maria Formation is correlated to several Argentinean lithostratigraphic units like Los Chanares, Ischigualasto, and Los Colorados (Barberena et al., 1985). Contrary to the Brazilian layers, the upper parts of the Argentinean strata have yielded some very interesting reptiles closely related to important archosaur groups like dinosaurs. Therefore the Santa Maria Formation has a great potential to yield this kind of fossils that would enhance our understanding of the Triassic vertebrate fauna in this part of the world.

\section{Botucatu Formation}

The Botucatu Formation is composed mainly by sandstones and represents the largest "fossil desert" known so far. Based on ichnological studies the age of those layers has long been regarded as Early Jurassic (Leonardi, 1994: 50), but recently some stratigraphic data suggest an Early Cretaceous age (Schultz, personal communication 1999).

This unit is very rich in ichnofossils, particularly in the region of Araraquara, São Paulo State. Several footprints and tracks, occasionally associated with traces of invertebrates, have been found, which are generally not very well preserved. Nevertheless, they show a large diversity with about 15 different ichnoforms (only one formally named, Leonardi, 1981) that are tentatively referred to dinosaurs and mammals (Leonardi, 1994). More detailed studies of those specimens are necessary in order to provide a better understanding of the ichnofauna preserved in the Botucatu Formation.

\section{Rio do Peixe Basin (Early Cretaceous)}

The Rio do Peixe Basin is a small interior basin of the northeastern part of Brazil. Situated in the State of Paraíba, the sedimentary rocks that form this tectonic feature are divided into three stratigraphic units. The basal one is the Antenor Navarro Formation, composed essentially of conglomerates and sandstones, that is overlain by the finer rocks (sandstones and shales) of the Sousa Formation. At the top of the sequence there are fine to medium grained sandstones that compose the Rio Piranhas Formation. The whole sequence is regarded as fluvial and was deposited possibly during the Early Cretaceous (Leonardi, 1994).

The only fossils found in those strata are dinosaurian footprints and trackways (Figure 2c). The richest sites are situated in the municipalities of Sousa and Antenor Navarro. Those ichnofossils suggest that a diverse dinosaurian fauna was present in this area during the Early Cretaceous. Theropod and sauropod tracks are more common, but some have been attributed to ornithischian and constitute the only record of this dinosaur clade in Brazil so far (Kellner, 1998).

\section{Crato Member, Santana Formation (Early Cretaceous, Araripe Basin)}

Perhaps the richest vertebrate fossil deposit of Brazil and one of the most important in the world is the Santana Formation of the Araripe Basin. Situated between the states of Ceará, Pernambuco, and Piauí, this stratigraphic unit is traditionally divided into three members: Crato, Ipubi, and Romualdo (Beurlen, 1971). The fossils of those strata are worldwide known for their exquisite preservation (see Maisey, 1991). However, what several researchers do not realize is that the
Santana Formation comprises actually two Lagerstätte, respectively formed by the sedimentary rocks of the Crato and Romualdo members (the latter being discussed elsewhere).

The Crato Member forms the lower section of the Santana Formation, situated above the Rio da Batateira Formation and below the Ipubi Member (Ponte and Ponte, 1996). This unit is composed of laminated limestones that were deposited in a lacustrine environment. Based on palynomorphs, their age is regarded as Aptian/Albian (Pons et al., 1990). Several outcrops are presently quarried for industrial and construction purposes, particularly in the State of Ceará, around the towns of Nova Olinda and Santana do Cariri (Figure 4a).

Besides insects and plants (see Maisey, 1991, for a review), the most common fossil in those layers is the gonorynchiform fish Dastilbe (Blum, 1991), from which several thousands are known. Proportionally more rarer, the ichthyodectiform Cladocyclus is present too (less than 100 specimens), represented mostly by small individuals, although some larger were also discovered (Kellner, personal observation). Recently two small specimens of coelacanthids were found and are presently being studied (Nuvens, personal communication 1999). There is also another undescribed fish found in those layers that probably is closely related to Calamopleurus (Amiidae; Campos personal observation).

Regarding tetrapods, the laminated layers of the Crato Member yielded several anurans, turtles (mostly juveniles), two kinds of lizards, and one crocodilian (Kellner, 1998: 657), all still undescribed. Although rare, some pterosaurs have also been discovered (Frey and Martill, 1994; Campos and Kellner, 1997), that belong to two different clades: Pteranodontoidea (sensu Kellner, 1996c) and Tapejaridae. More specimens have been collected recently, some showing evidences of the wing membrane (Sayão and Kellner, 1998, and Kellner, personal observation). Lastly, several feathers have been collected and were described (Martins Neto and Kellner, 1988; Kellner et al., 1994a), some showing even the presence of the color pattern (Kellner et al., 1999: 53).

Perhaps the most interesting questions of the fossil Lagerstätte of the Crato Member are the vertebrate fossils that have not been found: dinosaurs (including birds) and mammals. Due to the environmental conditions, it seems quite clear that those vertebrates must have been present during that time in the Araripe area and more collecting in those strata will certainly reveal them.

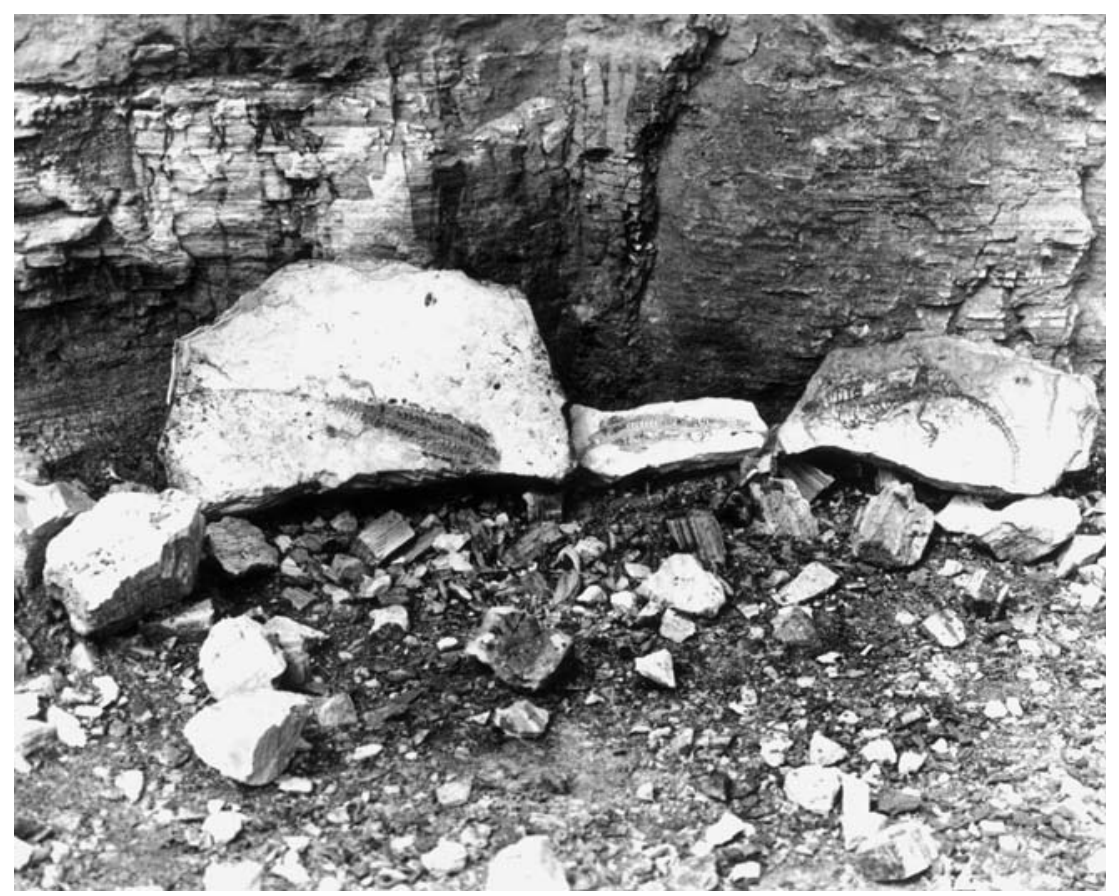

Figure 3 Mesosaur specimens from the Irati Formation (Permian). 


\section{Romualdo Member, Santana Formation (Early Cretaceous, Araripe Basin)}

The Romualdo Member forms the upper stratigraphical unit of the Santana Formation and is composed essentially of shales and marls. Coarser sediments (siltstones, fine-grained sandstones) are found in

a

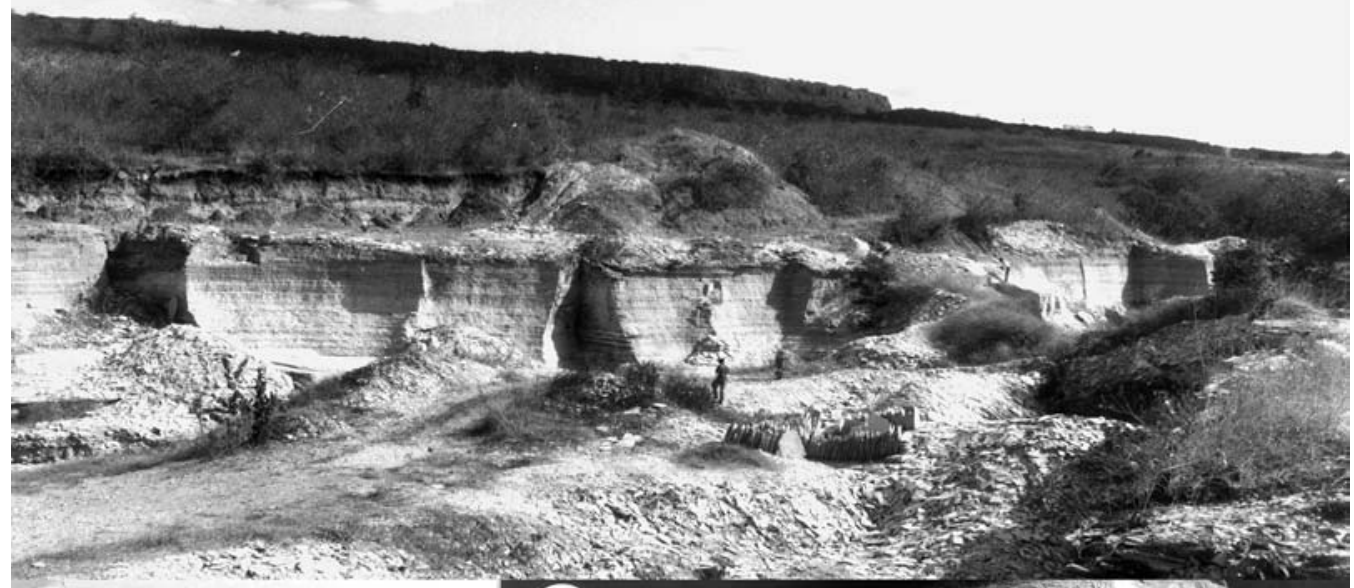

different parts of the section (Cavalcanti and Viana, 1990). It lays above the Ipubi Member (mainly composed of gypsum and black shales, also fossiliferous) and is overlain by the sandstones of the Exu Formation. Based on palynomorphs, the age of those rocks is regarded as Albian (Pons et al., 1990).

Fossils of the Romualdo Member are found in the shales and in calcareous nodules, the latter being extremely well preserved. Besides some invertebrates and plants, the most common fossil of this Lagerstätten are fishes (Figures $4 b-d$ ), with thousands (perhaps millions) of specimens. There are over 20 species known, represented by chondrichthyans, actinopterygians, and sarcopterygians (Santos and Valença, 1968; Maisey, 1991).

Among the most common taxa is Rhacolepis (Figure 4b), a pachyrhizodontid (Elopomorpha) of small size $(\sim 100-300 \mathrm{~mm})$, represented by two species (Maisey, 1991). Some specimens show the stomach content preserved, composed of shrimps (Kellner et al., 1994b). Preliminary estimates indicate that Rhacolepis and two more taxa, Vinctifer (Aspidorhynchidae, Halecostomi) and Tharrhias (Gonorynchiformes), form over $90 \%$ of all fish specimens known from this deposit.

Much less abundant are the pycnodontiforms Neoproscinetes and Iemanja, that are deep-bodied animals with tritoral teeth, probably used for crushing their food (e.g., mollusks, arthropods). The largest "predators" of the Romualdo sea were Calamopleurus (Amiidae) and Cladocyclus (Ichthyodectiformes) that could reach up to $2000 \mathrm{~mm}$. Extremely rare are Oshunia (Ionoscopidae, figure 4d) and Obaichthys, known respectively from five and three specimens.

Two elasmobranchs have also been reported from the Romualdo Member. One is Iansan (a ray formerly regarded as Rhinobatos) and the second is Tribodus, a hybodont shark (Brito and Ferreira, 1989), both represented by several (ca. 50100) specimens. Furthermore, this deposit has also provided two species of sarcopterygians (Coelacanthidae: Campos and

Figure 4 a-General view of the Araripe Basin between the towns of Nova Olinda and Santana do Cariri, showing outcrops of the Santana Formation, particularly the laminated limestones from the Crato member (Early Cretaceous); b - first Brazilian fossil to be figured, possible a specimen of Rhacolepis found in the Romualdo Member (taken from Spix and Martius, 18231831); c - skull of a coelacanth found in the Romualdo Member $(M N) ; d$ - fish in a typical nodule from the Romualdo Member (Oshunia). are also comparatively rare (FigWenz, 198

Although comparatively much rarer than the fishes, several specimens of reptilian groups (Figures 5,6) have also been found in the Romualdo Lagerstätte. There are at least four taxa of turtles. Three of them, Araripemys (Price, 1973; Meylan, 1996), Santanachelys (Hirayama, 1998), and a yet undescribed taxon (Campos, personal observation), have a dorsoventrally compressed shell and are regarded as marine animals. A fourth one (also undescribed) has 

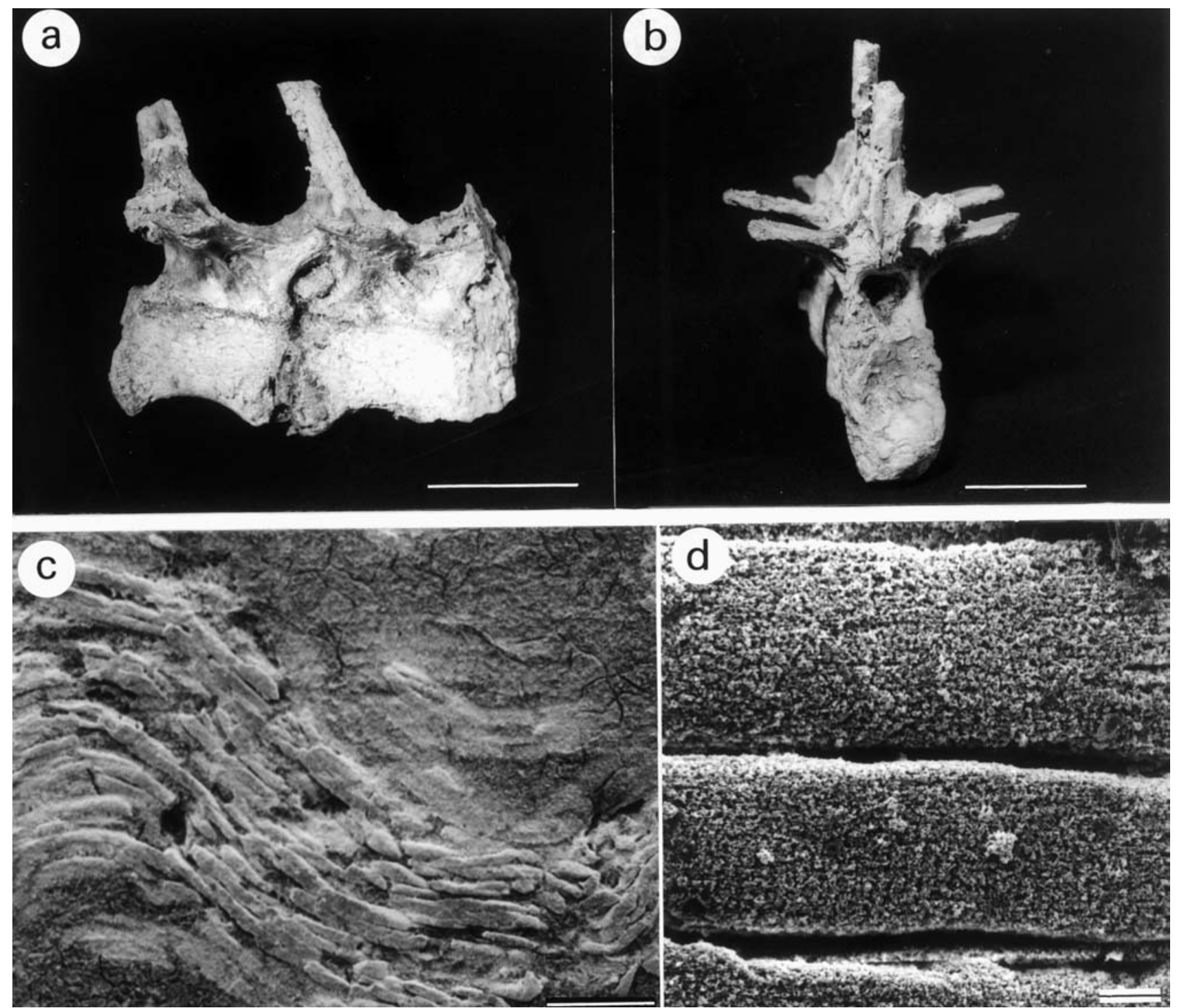

Figure 5 Dinosaur remains from the Romualdo Member, Santana Formation: $a, b-$ theropod caudals $(M N)$ in lateral $(a-s c a l e ~ b a r=50$ $\mathrm{mm}$ ) and posterior $(b$ - scale bar $=30 \mathrm{~mm})$ views; $c$ - soft tissue preservation showing muscle fibers (scale bar = 200 $\mu \mathrm{m}) ; d$ - detail of the muscle fibers, showing striations (scale bar $=10 \mu \mathrm{m}$ ).

a higher shell and had possible a more terrestrial habitat. Regarding crocodilians, two taxa were described: Araripesuchus (Price, 1959; Hecht, 1991) and Caririsuchus (Kellner, 1987). Araripesuchus was a small sized $(50-60 \mathrm{~cm})$ terrestrial animal that is known from three specimens (Figure 6a). Caririsuchus was comparatively larger (150 $\mathrm{cm}$ ) and is regarded as an aquatic form.

Dinosaur material is also rare (Figures 5a, b) and very few specimens were reported (Campos and Kellner, 1991; Kellner, 1996b). Two taxa were formally described: Irritator (Martill et al., 1996) and Angaturama (Kellner and Campos, 1996). Both were large animals representing Spinosauridae (Kellner, 1994; 1996b), a rare theropod clade previously recorded in the continental Cretaceous strata of Africa (see Kellner and Campos, 1996, for a review of spinosaurids). Small theropods are also found (Kellner, 1996a) but were not formally described. Some show soft tissue preserved in three dimensions (Kellner and Campos, 1998), that is extremely rare (Figures 5c, d).

The most common tetrapods of the Romualdo Member are pterosaurs, also known as flying reptiles (Figure 6b-e). Since the first specimen studied by Price (1971), a total of 14 species were described, but several are based on incomplete material. Most forms can be classified into two pterodactyloid clades: Anhangueridae and Tapejaridae. The Anhangueridae are toothed forms that are charac- terized by the presence of a rostral sagittal crest on the upper and lower jaw (Campos and Kellner, 1985; Wellnhofer, 1987, 1991; Kellner, 1996c). Differing from the latter, the members of the Tapejaridae are toothless and have an extremely large and bizarre sagittal crests, that extends from the rostral part backward above the caudal end of the skull (Kellner, 1989; Kellner, 1996c).

Some specimens from the Romualdo have soft tissue preserved in three dimension, particularly fishes (Martill, 1988) and more rarely in pterosaurs (Martill and Unwin, 1989; Kellner, 1990; 1996c,d; Figures 6c-e), dinosaurs (Kellner, 1996a,b; Figures 5c,d), and crocodilians (Kellner and Campos, 1998). No evidences of birds and mammals were recorded so far.

\section{Late Cretaceous continental strata (Bauru Basin)}

The most extensive Cretaceous continental sedimentary sequence in Brazil (and in South America) is formed by the strata that form the Bauru Group (Figure 2d). Deposited above the volcanic rocks of the Serra Geral Formation, those layers were divided into four formations: Caiuá, Santo Anastácio, Adamantina, and Marília (Soares et 

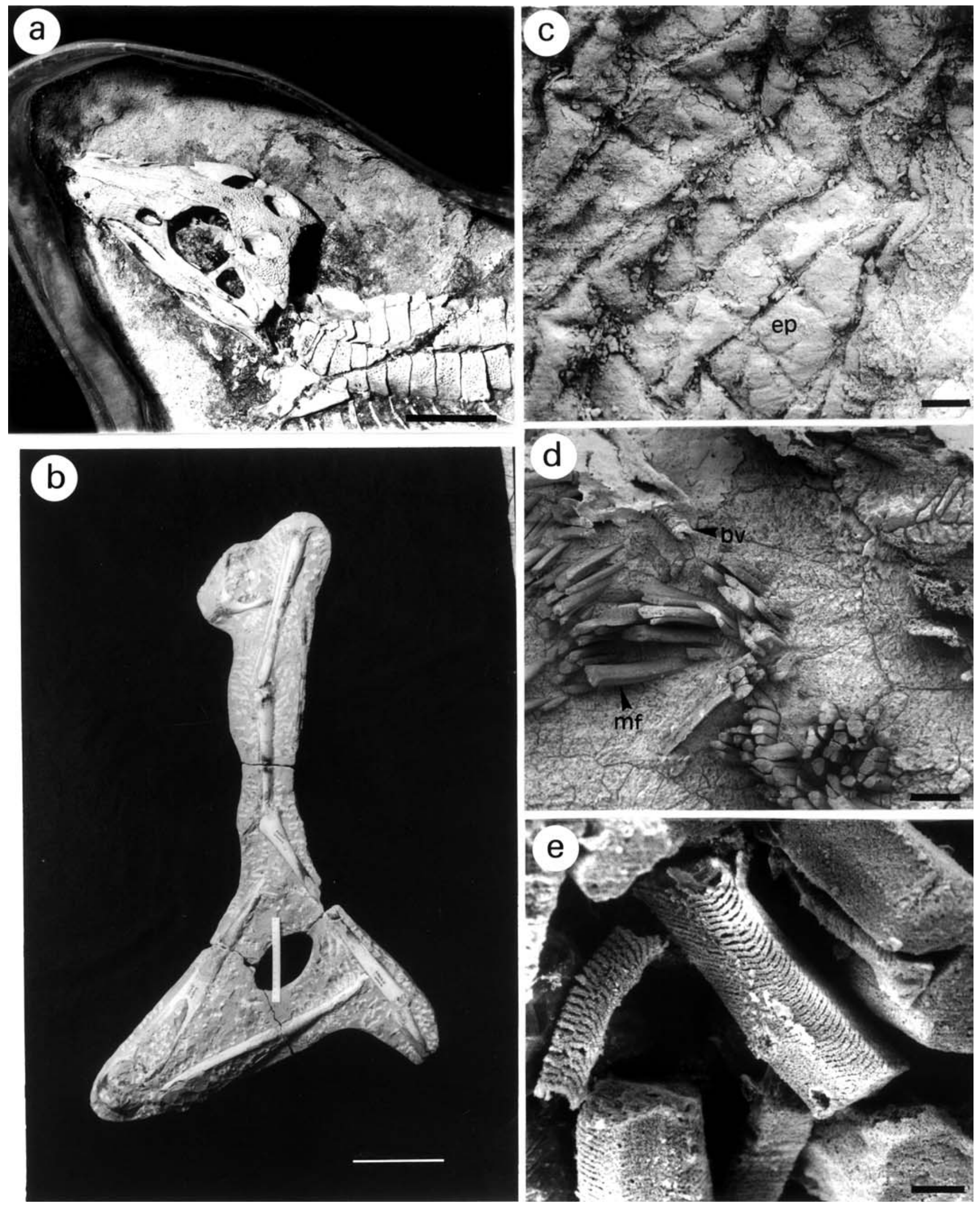

Figure 6 More fossils from the Romualdo Member, Santana Formation: $a$ - the crocodilian Araripesuchus (AMNH 24450; scale bar = $30 \mathrm{~mm}$ ); $b$ - partial pterosaur skeleton, still unprepared (AMNH; scale bar = $100 \mathrm{~mm})$; $c$ - soft tissue of a pterosaur, showing the outer surface of the epidermis (scale bar $=200 \mu \mathrm{m}) ; \boldsymbol{d}$ - muscle fibers $(\mathrm{mf})$ and blood vessel $(\mathrm{bv})$ of a pterosaur soft tissue (scale bar = $100 \mu \mathrm{m})$; $e$ - detail of a striated muscle fiber (scale bar $=10 \mu \mathrm{m}$ ). 
al. 1980). To this, Souza (1984) added the Uberaba Formation that outcrops in the State of Minas Gerais and is interdigitated with the Adamantina Formation. All those units are composed essentially by sandstones and siltstones, locally conglomeratic that were deposited in a semiarid environment by a fluvial meandering river system dur-
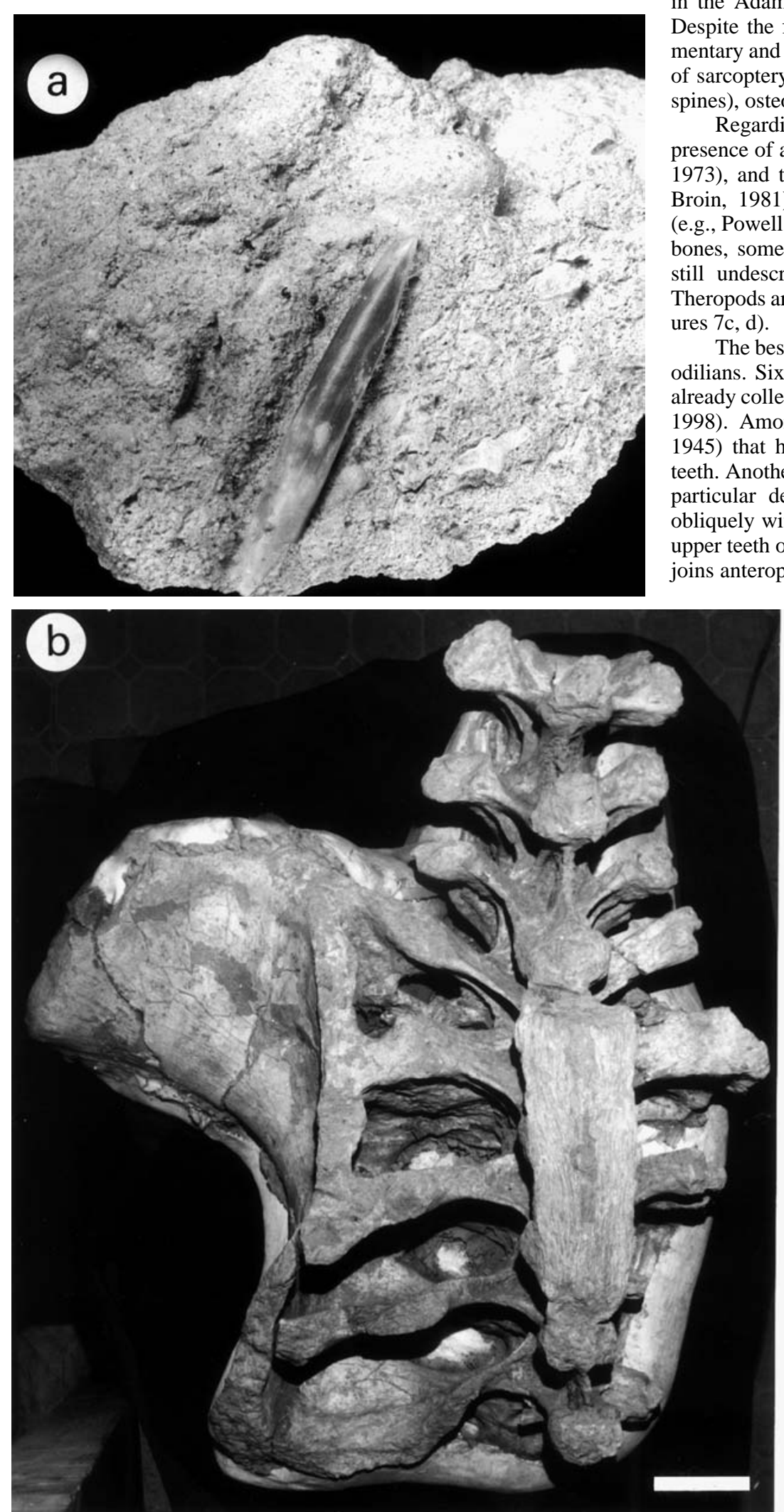

ing the Late Cretaceous. Although traditionally regarded as part of the Paraná Basin, Fernandes and Coimbra (1996) considered that those sedimentary rocks are the result of a distinct depositional area (and tectonic feature) which they named as the Bauru Basin.

Vertebrate fossils are quite common (Figures 7,8), particularly in the Adamantina and Marília Formations (Bertini et al., 1993). Despite the fact that most fish remains from those strata are fragmentary and incomplete (e.g., scales, teeth), they reveal the presence of sarcopterygians, lepisosteiforms, characiforms, siluriforms (e.g., spines), osteoglossiforms, and perciforms (Bertini et al., 1993).

Regarding tetrapods, the deposits of the Bauru Basin show the presence of anurans (Baez and Perí, 1989), lizards (Estes and Price, 1973), and turtles (e.g., Suarez, 1969; Price, 1953a; Campos and Broin, 1981). Dinosaurs are also present, particularly sauropods (e.g., Powell, 1987) that are known by isolated teeth (Figure 7a) and bones, sometimes articulated (Figure 7b, 8a). Most, however, are still undescribed (Campos and Kellner, 1991; Kellner, 1996b). Theropods are only known by a few isolated elements and teeth (Figures $7 \mathrm{c}, \mathrm{d}$ ).

The best represented reptile groups of the Bauru strata are crocodilians. Six species have been formally named, but based on the already collected specimens, the diversity was much higher (Kellner, 1998). Among the most interesting ones is Baurusuchus (Price, 1945) that has a high, laterally compressed skull with ziphodont teeth. Another bizarre form is Sphagesaurus (Price, 1950) that has a particular dentition (Figure 8b), with elliptical teeth positioned obliquely with respect to the long axis of the jaw. Furthermore, the upper teeth of this taxon has the posterolingual margin keel-like that joins anteroposterior keel of the lower dentition forming a powerful haring mechanism

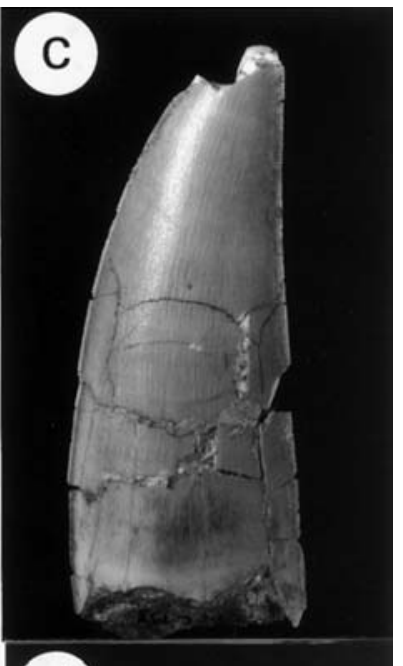
never reported in crocodilians before (Kellner et al., 1995). Both, Baurusuchus and Sphagesaurus, were predators that occupied terrestrial habitats and possible competed with theropod dinosaurs for prey.

The continental strata of the Bauru Group has also furnished some dinosaur eggs, that belonged to sauropods (Price, 1951) and theropods (Kellner et al., 1998).

Despite being the largest deposit of continental strata in Brazil, very few collecting was done in the Bauru Group so far. Based on other deposits of similar age, those strata have a large potential for important findings of terrestrial vertebrates such as avian and non-avian theropods, which are very scarcely known from this part of Gondwana.

Figure 7 Dinosaurs from the continental strata of the Bauru Group (Late Cretaceous) found in the region of Peirópolis, Minas Gerais State: a - titanosaurid sauropod tooth, still in the matrix; $b$ - titanosaurid sauropod pelvis, in dorsal view (scale bar $=100 \mathrm{~mm})$.; $c, d$ - theropod tooth in lingual $(\mathrm{c})$ and posterior $(\mathrm{d})$ views $($ scale bar $=10 \mathrm{~mm})$. 


\section{Pernambuco- Paraíba Basin}

The Pernambuco-Paraíba Basin is formed by Cretaceous, Tertiary, and Quaternary strata that outcrop between Recife and João Pessoa in the northeastern part of Brazil (Figure 2e). The Cretaceous sediments are grouped in the Beberibe and Gramame formations, followed by the Paleocene Maria Farinha Formation and covered by the Tertiary deposits of the Barreiras Formation. Regarding fossil vertebrates, the most important are the Gra-

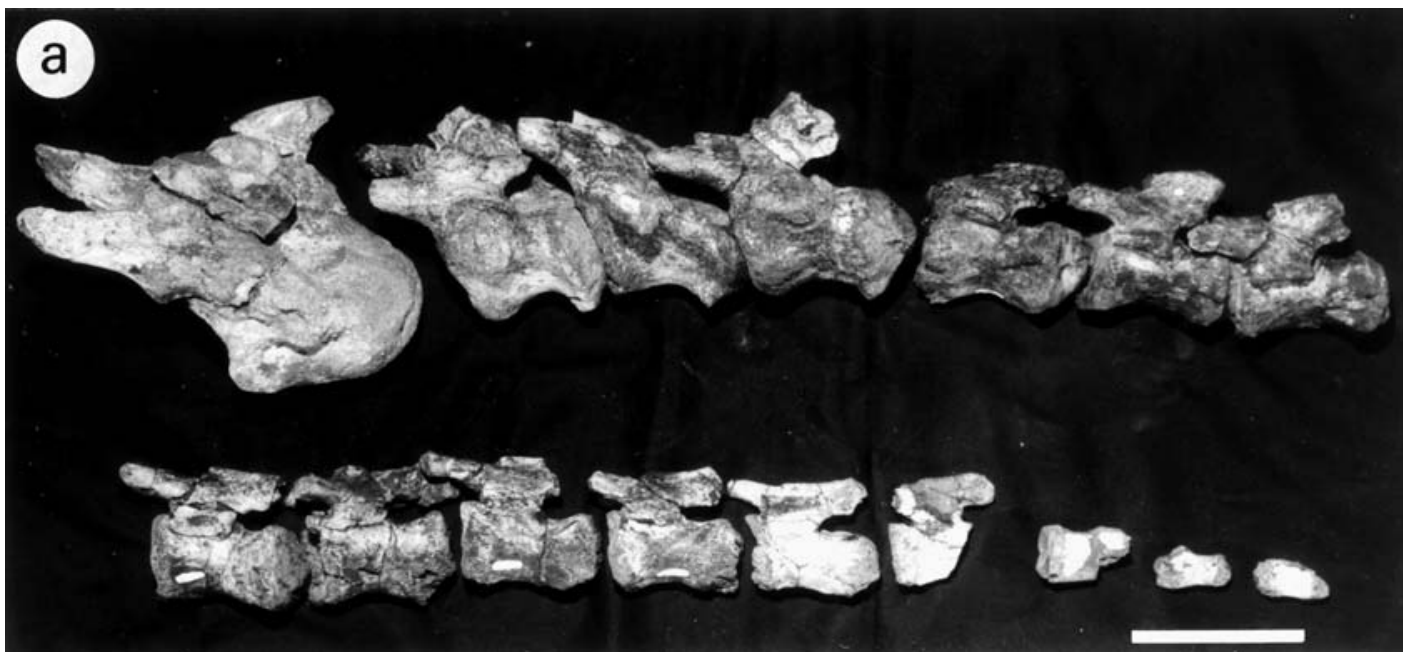

mame and Maria Farinha units. The limit between those formations is marked by a high concentration of iridium that indicates the $\mathrm{K} / \mathrm{T}$ boundary in that section. Fossils are mostly fragmentary and were found during the extensive mining activity that is being carried out in this region.

The Gramame Formation is composed by limestones that have phosphate concentrations. Those strata were formed in a marine environment, reflecting the marine transgression occurred in the northeastern part of Brazil during the Late Cretaceous (Maastrichtian).

Despite the fragmentary nature of the fossils, this deposit is very important since it is one of the few that contain remains of marine reptiles. The most abundant are mosasaur teeth and vertebrae (Price, 1953b, 1957) that indicate the presence of at least four different groups (Azevedo and Carvalho, 1997). Recently the presence of plesiosaur has also been reported, based on one tooth, some vertebrate, fragmentary ribs (Carvalho et al., 1997), and one incomplete cranial bone (Carvalho personal communication, 1999). Furthermore, those strata yielded the first pterosaur known from South America, which is related with nyctosaurid taxa found in the Niobrara strata of the United States (Price, 1953c). Isolated fish material is also found, mostly referable to elasmobranchs and actinopterygians.

The Maria Farinha Formation is also composed of limestones, which reflect a regressive phase that affected the northeastern part of Brazil during the Paleocene. This unit is very rich in fossil invertebrates, but occasionally some vertebrates are found too. The most important are several fish specimens, particularly elasmobranchs. Regarding tetrapods, only remains of marine crocodilians (teeth and vertebrae, Carvalho personal communication, 1997) and turtles (Campos and Broin, 1981) have been found so far.

\section{São José de Itaboraí Basin (Paleocene)}

Being the most expressive Tertiary mammal deposit in Brazil, the São José de Itaboraí Basin is formed by a sequence of different limestone layers that are regarded of Paleocene age. Nowadays this basin is filled up with water impeding any collecting activity.

Among the mammals, the strata of this basin yielded several species of marsupials (e.g., didelfids like Eobrasilia and Marmosopsis), litopternids (e.g., Anisolambda), notoungulates (e.g., Colbertia), xenungulates (Carodnia) and several more (see, e.g., Couto, 1979; Marshall, 1987).

Besides mammals, the Itaboraí Basin has furnished also remains of several groups of reptiles such as turtles (Campos and Broin, 1981), snakes, and crocodilians. By far the best-represented are lizards, from which hundreds of bones were found (Estes and Price, 1973), but were not studied yet. Completing the fossil verte-

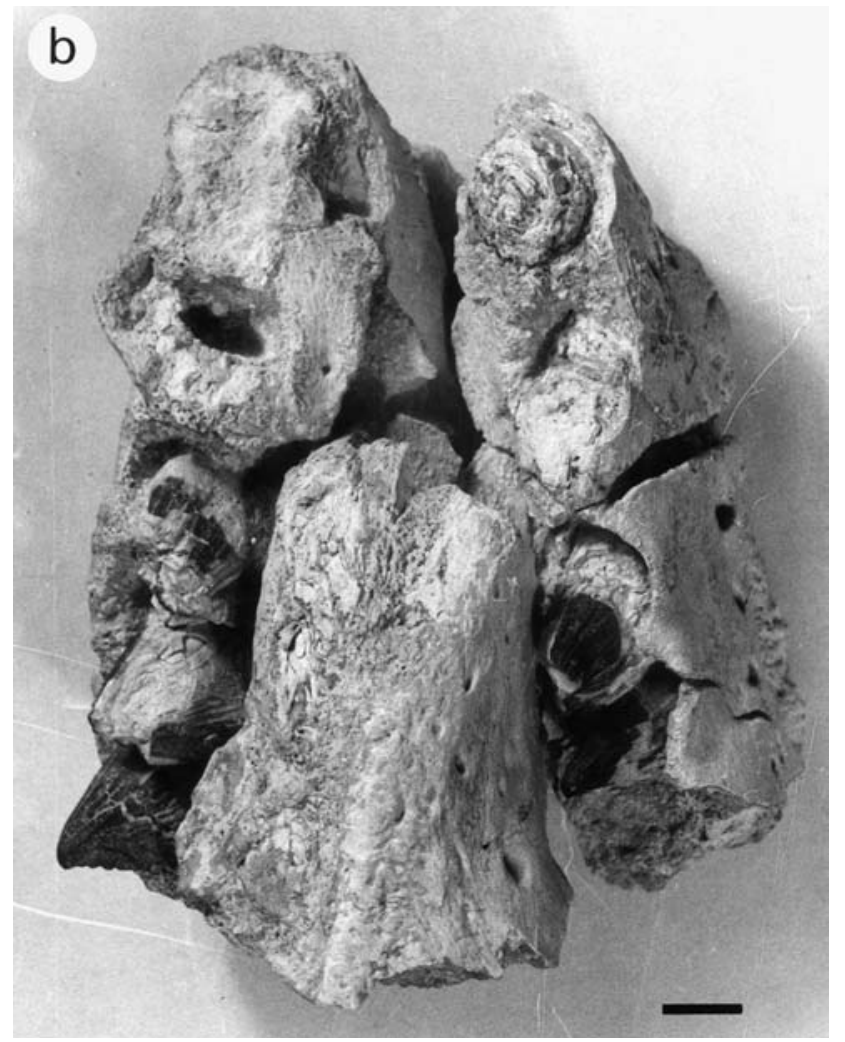

Figure 8 Fossils from the continental strata of the Bauru Group (Late Cretaceous): a - incomplete caudal sequence of a titanosaurid sauropod found in Alvares Machado, São Paulo State (scale bar $=100 \mathrm{~mm}) ; b$ - ventral view of the crocodilian Sphagesaurus (DGM 1411-R; Presidente Prudente, São Paulo State; (scale bar $=10 \mathrm{~mm})$.

brate faunal list of this deposit, there are two taxa of birds (e.g., Figure 9), known by incomplete specimens (Alvarenga, 1983; 1985b).

\section{Taubaté Basin (Oligo-Miocene)}

Situated in the State of São Paulo, the Taubaté Basin is an elongated structure, with the main axis directed for about $150 \mathrm{~km}$ in the northeastern - southwestern direction and varying in width between and 10 and $25 \mathrm{~km}$. It is essentially composed of dark shales that were deposited during the Oligo-Miocene (Figure 2f). The sedimentary rocks are divided into two formations, Tremembé and Caçapava (Petri and Fúlfaro, 1988), the former being the most fossiliferous. 
The outcrops of the Tremembé Formation are particularly rich in actinopterygian fish, with about 10 taxa known (e.g., Travassos and Santos, 1955). Those layers can also be considered the richest deposits of birds, with six species recognized until now (Alvarenga, 1982; 1985a; 1988, 1990; 1993; 1995). The Tremembé Formation has also furnished remains of amphibians, turtles, and caimans, most still undescribed. Some snake specimens have also been found and are presently under study (Capilla, 1994). Regarding mammals, the most interesting specimen is Tadarida, the only Tertiary bat known in this country (Couto, 1956). Some specimens of notoungulates were also found (Couto, 1979; Soria and Alvarenga, 1989).

\section{Tertiary deposits of the Amazon Basin}

The Tertiary deposits of the Amazon Basin outcrop in several parts of the main rivers, particularly Solimões (Amazonia), Alto Purus and Alto Juruá (Acre). The sedimentary rocks are pelitic with locally coarser lenses (siltstones and sandstones). Depending on the author, those rocks are called the Solimões or Pebas Formation (Petri and Fúlfaro, 1988). The ages of those strata are presently regarded as Miocene-Pliocene (Bocquentin and Janoo, 1997).

Among the most interesting fossils from this basin are very large crocodilian reptiles like Purussaurus and Mourasuchus (Price, $1964 ; 1967)$ and undescribed chelonians (Campos and Broin, 1981). Also fossil birds tend to be large, like the Anhinga material presently under study (Bocquentin and Janoo, 1997). There is also a diverse fauna of mammals, particularly rodents, mostly undescribed.

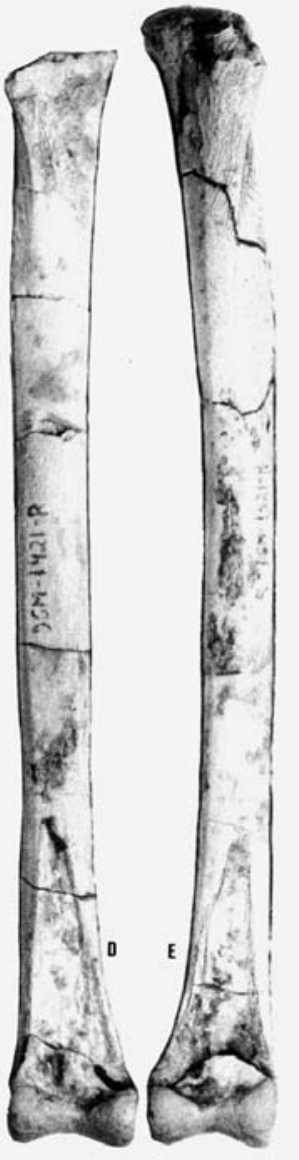

a

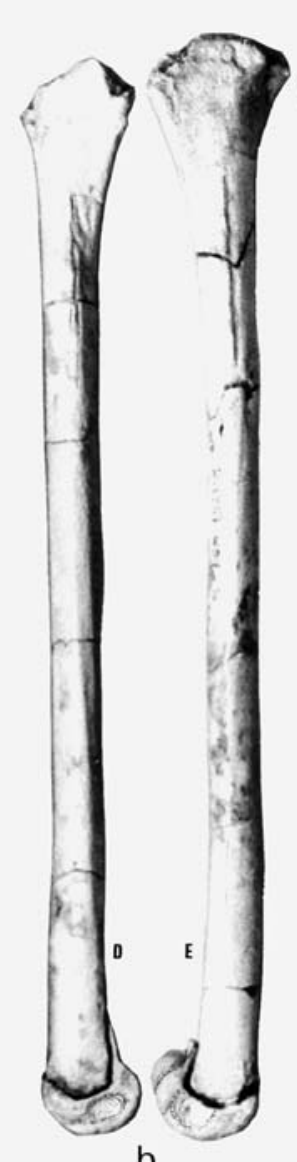

b

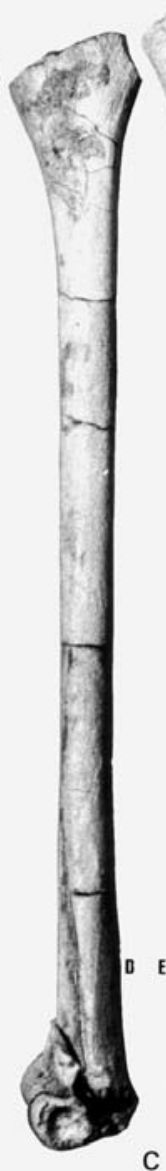

C

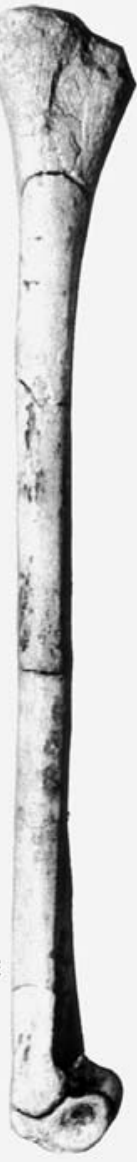

\section{Pleistocene deposits}

Quaternary deposits of Brazil are found in different regions of the country. Several are known since the last century, particularly due to the work of the Danish paleontologist Peter Wilhelm Lund. Lund explored many limestone caves, for all in Minas Gerais, discovering and describing a large number of Pleistocene mammal taxa. Some of the richest calcareous caves are the Lapa do Mosquito, Maquiné cave and Lagoa Santa. Most caves are related to the limestone deposits of the Bambuí Group, extending from Minas Gerais into Southern Bahia. During the nineties, more deposits in those states were discovered (e.g., Couto, 1979; Cartelle, 1994).

Pleistocene deposits were also found in other parts of Brazil. Vidal (1946, 1955,1959), for example, collected in the Pernambuco State gathering a very rich and diverse mammalian material. Couto (1951) also directed field trips to the northeastern part of Brazil, discovering some of the most fossiliferous units in the states of Paraíba and Ceará State, where herbivorous mammalian taxa predominated. Other important Pleistocene deposits of the northeastern part of Brazil are found in São Raimundo Nonato, Piauí State.

In the southern and southeastern part of the country there are several Pleistocene deposits, most discovered by Couto (1959; 1973; 1978) and Cunha (1959). Two representative sites are Alvares Machado in the State of São Paulo (Figure 10a) and Santa Vitória do Palmar in the State of Rio Grande do Sul (Figure 10b-d; Cunha and Nunan, 1980; Cunha and Magalhães, 1981).

Among the most common Pleistocene mammal taxa are sloths (Edentata) like Megatherium, Eremotherium, Scelidodon, and Mylodonopsis. Marsupials (e.g., Didelphis), dasypodids (e.g., Pampatherium, Holmesina), bats (Desmodus), gliptodonts (e.g., Hoplophorus, Glyptodon), rodents (e.g., Oryzomys, Akodon, Cavia, Agouti), carnivores (e.g., Protocyon, Arctotherium, Smilodon), proboscids (Haplomastodon), artiodactyls (e.g., Paleolama), perissodactyls (e.g., Equus, Hippidion, Tapirus), and primates (e.g., Protopithecus) are also present (see, e.g., Couto, 1979 and Cartelle, 1994, for a review).

\section{Discussion}

As presented above, the Brazilian territory has several fossil Lagerstätten of different geologic ages. So far the highest diversity of paleovertebrate faunas is present in Cretaceous terrains, particularly in the Araripe Basin (Crato and Romualdo members of the Santana Formation), and in Pleistocene deposits found in limestone caves.

Regarding fossil "fish", there is a good knowledge about the faunas present in Cretaceous stratigraphic units like Codó, Santana, and Ilhas formations, and the Tertiary Pirabas and Taubaté formations. But very little is know about the Devonian and Permian taxa (Richter, 1985). Also surprising is the limited knowledge of the continental fish fauna from the Bauru Basin, which might be explained by poor preservation and incompleteness of most specimens.

A recent review of the reptilian faunas also shows some surprises. From the 83 taxa identified on the specific or generic level, 19 belong to pterosaurs, 14 to crocodilians, and 13 to turtles. Regarding dinosaurs, only 4 have been described ( 3 non-avian theropods and one sauropod). Except for footprints and trackways, ornithischian dinosaurs are completely absent. This lack of knowledge, particularly of dinosaurs, is incongruent with the extensive Cretaceous strata present in this country (Kellner, 1998). The best-known reptilian fauna comes from the Santana Formation (particularly the Early Cretaceous Romualdo Member), followed by Santa Maria Formation (Triassic).

The Brazilian avian faunas are only known from the Paleocene strata of the São José de Itaboraí Basin and the Oligo-Miocene Tremembé Formation (Taubaté Basin). Except for feathers, nothing is known about the Mesozoic avian fauna.

Figure 9 Tibiae of Diogenornis (Rheiformes, Ratite, Aves) from the São José de Itaboraí Basin (Paleocene). Scale bar $=50 \mathrm{~mm}$. 


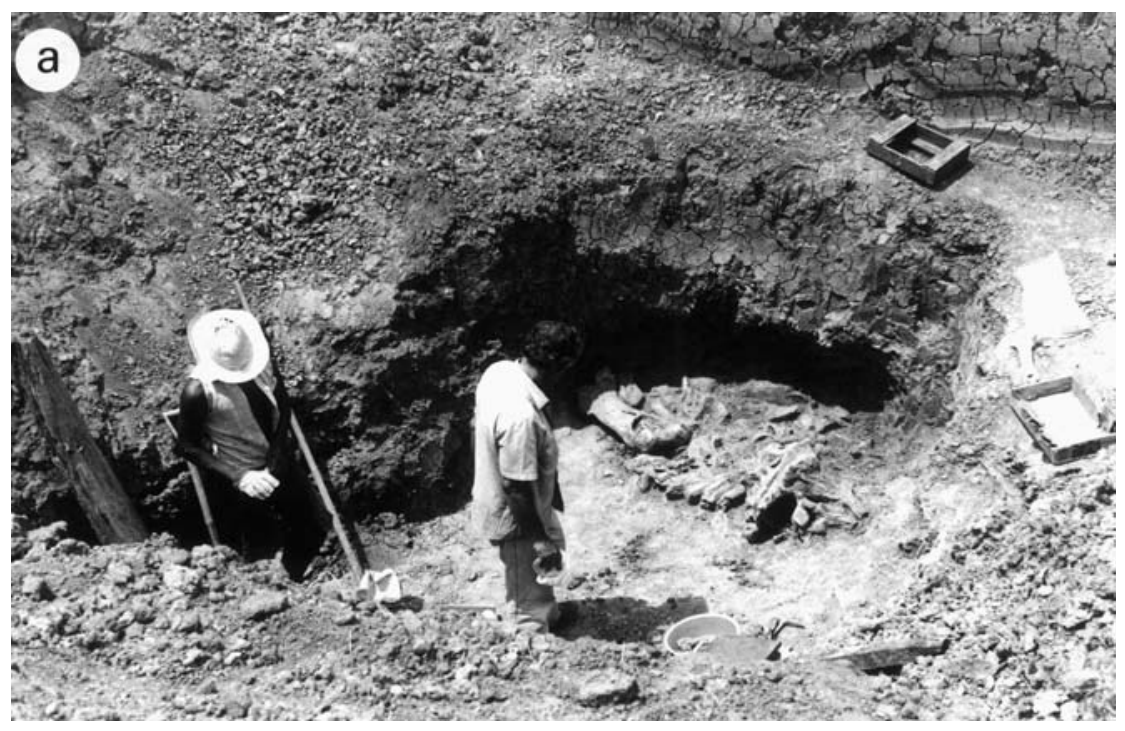

comparatively well know. Nevertheless, very little is known about the Pleistocene reptilian and fish faunas.

To conclude, vertebrate paleontology in Brazil has shown a substantial growth during the last decades, but there is still much work to be done to reach the same knowledge of more developed countries (e.g., Germany, United States). It is necessary to carry out more and continuous fieldwork and search for new material. This is particularly true for the Late Cretaceous strata, since they are, paradoxically, the poorest known despite their large extensions in this country. Also, comparing to other Late Cretaceous deposits of the world, the Brazilian vertebrate diversity known so far is very poor. Perhaps the employment of various collecting techniques (e.g., screen washing for small vertebrates such as anurans, lizards, and mammals) and systematic field expedition could provide a better knowledge of the Brazilian vertebrate faunas, particularly of the Cretaceous.

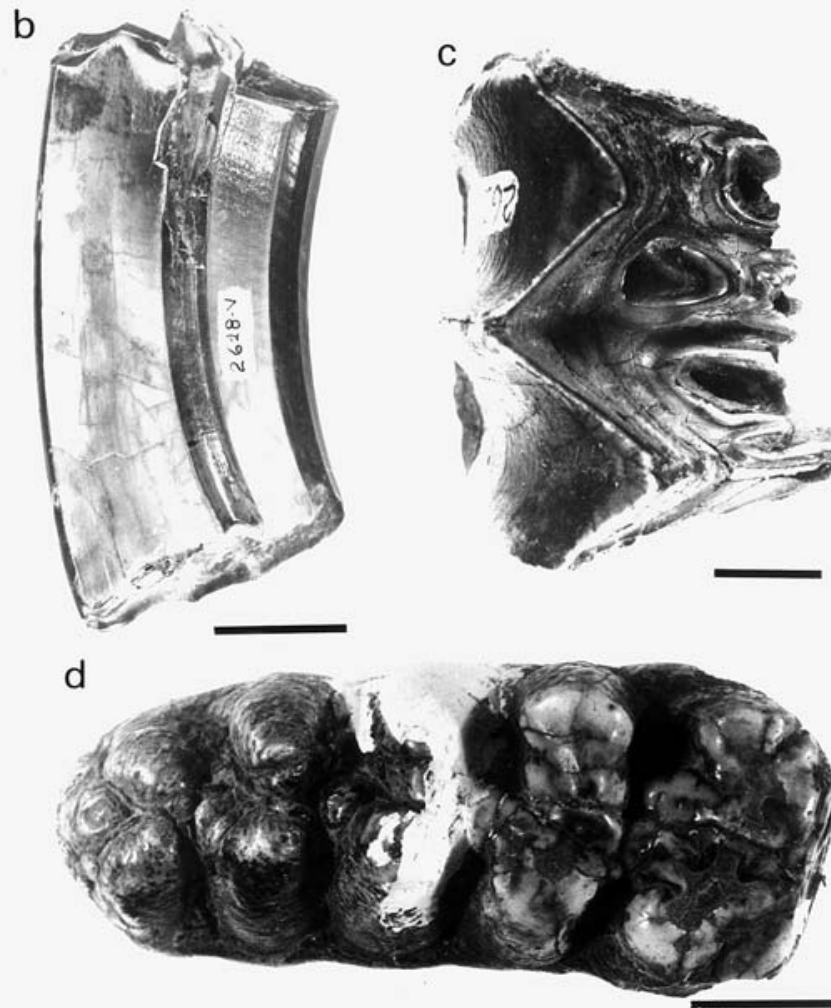

Figure 10 Pleistocene mammals: a - excavation of Pleistocene deposits at Alvares Machado, São Paulo State; b - tooth of Toxodon (scale bar $=30 \mathrm{~mm}$ ); $\boldsymbol{c}$ - tooth of Xenorhinotherium (scale bar $=10 \mathrm{~mm}) ; \mathrm{d}$ - tooth of Haplomastodon (scale bar $=30$ mm); b-d were collected at Vitória do Palmar (Rio Grande do Sul State).

Apart from a fragmentary lower jaw (Bertini et al, 1993), nothing is known about the Brazilian Mesozoic mammals. The Tertiary mammalian fauna is only well known at the São José de Itaboraí Basin due to extensive collecting done in the past. There are also hundreds of specimens available at collections that have not been studied yet. The latter is also true for the reptilian fauna of this Lagerstätten, particularly lizards.

Regarding Pleistocene deposits, work done in the last five decades has shown a great variety of mammalian taxa and can be considered one area of the Brazilian vertebrate paleontology that is

\section{Acknowledgements}

We would like to thank Deise D. R. Henriques (Museu Nacional/UFRJ), Cibele Schwanke (UERJ), Luciana B. Carvalho (MN/UFRJ), and Herculano M. F. Alvarenga for comments and suggestions on this manuscript. Luciana B. Carvalho is also thanked for sharing some unpublished information regarding the marine reptiles from the Paraíba-Pernambuco Basin.

We also thank Luciana B. Carvalho for providing the picture of the section at the Paraíba-Pernambuco Basin (Figure 2e) and Alberto B. Carvalho for the picture of the Taubaté Basin (Fig. 2f). Figures 3 and 10 were obtained from the picture collection that belonged to Dr. Fausto L. S. Cunha (housed at the MN/UFRJ); Figure $8 \mathrm{~b}$ from the picture collection of Llewellyn I. Price (housed at the DNPM/RJ); and Figure 9 from the archives of the Museu Nacional (MN/UFRJ). The remaining figures were taken by one of the authors (Kellner).

\section{References}

Alvarenga, H. M. F., 1982, Uma gigantesca ave fóssil do Cenozóico brasileiro: Physornis brasiliensis sp. n.: An. Acad. Bras. Ci., v. 54, no. 4, pp. 697-712.

Alvarenga, H. M. F., 1983, Uma ave ratitae do Paleoceno brasileiro: bacia calcária de Itaboraí, estado do Rio de Janeiro, Brasil: Bol. Mus. Nac., v. 41, pp. 1-7.

Alvarenga, H. M. F., 1985a, Notas sobre os Cathartidae (Aves) e descrição de um novo gênero do Cenozóico brasileiro: An. Acad. Bras. Ci., v. 57, no. 3, pp. 349-357.

Alvarenga, H. M. F., 1985b, Um novo Psilopteridae (Aves: Gruiformes) dos sedimentos terciários de Itaboraí, Rio de Janeiro, Brasil, in Campos, D. A., Ferreira, C. S., Brito, I. M., and Viana, C. F., eds, Coletânea de trabalhos paleontológicos: Brasília, DNPM, pp. 17-20.

Alvarenga, H. M. F., 1988, Ave fóssil (Gruiformes: Rallidae) dos folhelhos da bacia de Taubaté, estado de São Paulo, Brasil: An. Acad. Bras. Ci., v. 60, no. 3, pp. 321-328.

Alvarenga, H. M. F., 1990, Flamingos fósseis da bacia de Taubaté, estado de São Paulo, Brasil: descrição de nova espécie: An. Acad. Bras. Ci., v. 62, no. 4, pp. 335-345.

Alvarenga, H. M. F., 1993, Paraphysornis novo gênero para Physornis brasiliensis Alvarenga, 1982 (Aves: Phorusrhacidae): An. Acad. Bras. Ci., v. 62 , no. 4 , pp. 335-345.

Alvarenga, H. M. F., 1995, Um primitivo membro da ordem Galliformes (Aves) do Terciário médio da bacia de Taubaté, estado de São Paulo, Brasil: An. Acad. Bras. Ci., v. 62, no. 4, pp. 335-345.

Andreis, R. R., Bossi, G. E., and Montardo, D. K., 1980, O grupo Rosário do Sul (Triássico) no Rio Grande do Sul - Brasil: 31st Congresso Brasileiro de Geologia, 1980, Anais, v. 2, pp. 659-673. 
Araújo, D. C. F., 1976, Taxonomia e relações dos Proganosauria da bacia do Paraná: An. Acad. Bras. Ci., v. 48, no. 1, pp. 91-116.

Araújo, D. C. F., 1985, Sobre Pareiasaurus americanus sp. nov., do Permiano Superior do Rio Grande do Sul, Brasil. I - Diagnose específica: An. Acad. Bras. Ci., v. 57, no. 1, pp. 63-66.

Azevedo, S. A. K., and Carvalho, L. B., 1997, Proposta de classificação para os répteis marinhos (Mosasauridae: Lepidosauria) do Cretáceo Superior da bacia Pernambuco-Paraíba, Brasil: 15th Congresso Brasileiro de Paleontologia, São Pedro, 1997, Boletim de resumos, p. 96.

Azevedo, S. A. K., Schultz, C. L., and Barberena, M. C., 1990, Novas evidências bioestratigráficas e paleoecológicas na análise da evolução explosiva dos rincossauros do Triássico: Paula-Coutiana, v. 4, pp. 23-33.

Baez, A. M., and Perí, S., 1989, Baurubatrachus pricei, nov. gen., nov. sp., un anuro del Cretácico Superior de Minas Gerais, Brasil: An. Acad. Bras. Ci., v. 61 , no. 4 , pp. 447-458.

Barberena, M. C., 1982, Uma nova espécie de Proterochampsa (P. nodosa, sp. nov) do Triássico do Brasil: An. Acad. Bras. Ci., v. 54, no. 1, pp. 127141.

Barberena, M. A., 1998. Australerpeton cosgriffi n.g., n.sp., a Late Permian rhinesuchoid amphibian from Brazil: An. Acad. Bras. Ci., v. 70, no. 1, pp.125-137.

Barberena, M. A., and Dias, E. V., 1998, On the presence of a short-snouthed rhinesuchoid amphibian in the Rio do Rasto Formation (Late Permian of Paraná Basin, Brazil): An. Acad. Bras. Ci., v. 70, no. 3, pp. 465-468.

Barberena, M. C., Araújo, D. C., and Lavina, E. L., 1985, Late Permian and Triassic tetrapods of Southern Brazil: Nat. Geo. Res., v. 1, pp. 5-20.

Bertini, R. J., Marshall, L.G., Gayet, M., and Brito, P., 1993, Vertebrate faunas from the Adamantina and Marília formations (Upper Baurú Group, Late Cretaceous, Brazil) in their stratigraphic and paleobiogeographic context: N. J. Geol. Paläont, Abh, v. 188, no. 1, pp. 71-101.

Beurlen, K., 1971, As condições ecológicas e faciológicas da formação Santana na chapada do Araripe (Nordeste do Brasil): An. Acad. Bras. Ci., v. 43, supl., pp. 411-415.

Bocquentin, J., and Janoo, A., 1997, Uma nova espécie de Anhinga (Pelecaniformes, Anhingidae) proveniente do Neógeno da Amazônia Sul-Ocidental: 15th Congresso Brasileiro de Paleontologia, São Pedro, 1997, Boletim de resumos, p. 111

Bonaparte, J. F., and Barberena, M. C., 1987, Thrinaxodon brasiliensis sp. nov., a primeira ocorrência de cinodontes galessauros para o Triássico do Rio Grande do Sul: 10th Congresso Brasileiro de Geologia, Rio de Janeiro, 1987, Anais, pp. 67-76.

Blum, S., 1991, Dastilbe Jordan, 1910, in Maisey, J. G., ed., Santana fossils, an illustrated atlas: Neptune City, NJ, T.F.H., pp. 274-283.

Brito, P. M., and Ferreira, P. L. N., 1989, The first hybodont shark, Tribodus limae n. g., n. sp., from the Lower Cretaceous of Chapada do Araripe (North-East Brazil): An. Acad. Bras. Ci, v. 61, no. 1, pp. 53-57.

Campos, D. A., and Broin, F., 1981, Tartarugas fósseis do Brasil: An. Acad. Bras. Ci, v. 53, no. 1, pp. 210-211.

Campos, D. A., and Kellner, A. W. A., 1985, Panorama of the flying reptiles study in Brazil and South America: An. Acad. Bras. Ci., v. 57, no. 4, pp. 453-466.

Campos, D. A., and Kellner, A. W. A., 1991, Dinosaurs of the Santana Formation with comments on other Brazilian occurrences, in Maisey, J. G., ed., Santana fossils; an illustrated atlas: Neptune City, NJ, T.F.H., pp. 372-375

Campos, D. A., and Kellner, A. W. A., 1997, Short note on the first occurrence of Tapejaridae in the Crato Member (Aptian), Santana Formation, Araripe Basin, Northeast Brazil: An. Acad. Bras. Ci., v. 69, no. 1, pp. 8387.

Campos, D. A., and Wenz, S., 1982, Première découverte de coelacanthes dans le Crétacé Inférieur de la Chapada do Araripe (Brésil). Compt. Rendus Acad. Sci. Paris, II, v. 294, pp. 1151-1154.

Capilla, R., 1994, Um ofídio da formação Tremembé, bacia de Taubaté - SP: An. Acad. Bras. Ci., v. 66, no. 2, p. 253.

Cartelle, C., 1994, Tempo passado; mamíferos do Pleistoceno em Minas Gerais: Belo Horizonte, Palco, 132 pp.

Carvalho, L. B., Azevedo, S. A. K., and Capilla, R., 1997, Evidências da presença de plesiossauros (Sauropterygia: Elasmosauridae) na bacia Pernambuco-Paraíba, Neocretáceo do Nordeste brasileiro: An. Acad. Bras. Ci., v. 69 , no. 3 , p. 434.

Cavalcanti, V. M. M., and Viana, M. S. S., 1990, Faciologia dos sedimentos não-lacustres da formação Santana (Cretáceo Inferior da bacia do Araripe, Nordeste do Brasil): 1st Simpósio sobre a Bacia do Araripe e Bacias Interiores do Nordeste, Crato, 1990, Atas, pp. 193-207.

Colbert, E. H., 1970, A saurischian dinosaur from the Triassic of Brazil: Amer. Mus. Nov., no. 2405, pp. 1-39.
Copper, P., 1977, Paleolatitudes in the Devonian of Brazil and the FrasnianFamennian mass extinction: Palaeogeography, Palaeoclimatology, Palaeoecology, v. 21 , no. 3, pp. 165-207.

Couto, C. P., 1951, Sobre alguns mamíferos fósseis do Ceará: Arquivos do Museu Nacional, v. 42, pp. 195-210.

Couto, C. P., 1956, Une chauve-souris fossile des argiles feuilletées Pléistocènes de Tremembé, État de São Paulo (Brésil). Actes IV Congrès Intern. Quaternaire, v. 1: 343-347.

Couto, C. P., 1959, Uma pequena preguiça terrícola de São Paulo: An. Acad. Bras. Ci., v. 31, no. 1, pp. 91-107.

Couto, C. P., 1973, Edentados fósseis de São Paulo: An. Acad. Bras. Ci., v. 45 , no. 2 , pp. $261-275$

Couto, C. P., 1978, Mamíferos fósseis do Pleistoceno do Espírito Santo: An. Acad. Bras. Ci., v. 50 , no. 3, pp. 365-379.

Couto, C. P., 1979, Tratado de Paleomastozoologia: Rio de Janeiro, Academia Brasileira de Ciĺncias, 590 pp.

Cunha, F. L. S., 1959, Mamíferos fósseis do Pleistoceno do Rio Grande do Sul. I - ungulados: Boletim Divisão de Geologia e Mineralogia, no. 202, pp. $1-47$.

Cunha, F. L. S., and Magalhães, R. M. M., 1981, Cervídeos pleistocênicos de Santa Vitória do Palmar, Rio Grande do Sul, Brasil: 2nd Congresso Latino-Americano de Paleontologia, 1981, Anais, pp. 795-803.

Cunha, F. L. S., and Nunan, G. W. A., 1980, Pleistocenic marine vertebrates (Sciaenidae and Ballaenopteridae) from the littoral of Santa Vitória do Palmar, RS, Brazil: Anais do 31st Congresso Brasileiro de Geologia, 1980, Anais, v. 5, pp. 3049-55.

Estes, R., and Price, L. I., 1973, Iguanid lizard from the Upper Cretaceous of Brazil: Science, v. 180, pp. 748-751.

Faccini, U.F., Scherer, C.M.S., and Nowatzki, C. H., 1995, Breve panorama sobre a estratigrafia do Permo-Triássico da borda sudeste da bacia do Paraná: conjecturas e refutações: Comun. Mus. CiÍnc. Tecnol. UBEA/PUCRS, sér. Ci. Terra, v. 1, pp 13-18.

Fernandes, L.A., and Coimbra, A. M., 1996, A bacia Bauru (Cretáceo Superior, Brasil): An. Acad. Bras. Ci., v. 68, no. 2, pp. 195-205.

Frey, E., and Martill, D., 1994, A new pterosaur from the Crato Formation (Lower Cretaceous, Aptian) of Brazil: N. J. Geol. Paläont., Abh., v. 194 no. $2 / 3$, pp. $379-412$.

Gauthier, J. A., Kluge, A. G., and Rowe, T., 1988, The early evolution of the Amniota, in Benton, M. J., ed, The Phylogeny and Classification of the Tetrapoda: Oxford, Clarendon, pp. 103-155.

Hecht, M. K., 1991, Araripesuchus Price, 1959, in Maisey, J. G., ed, Santana fossils; an illustrated atlas: Neptune, NJ, T. F. H., pp. 342-347.

Hirayama, R., 1998, Oldest known sea turtle: Nature, v. 392, pp. 705-708.

Huene, F., 1942, Die fossilen Reptilien des S damerikanischen Gondwanalandes: M,nchen, C. H. Beck'sche, 332 pp.

Janvier, P., and Melo, J. H. G., 1987, Late Devonian actinopterygian scales from the Upper Amazon Basin, Northwestern Brazil: An. Acad. Bras. Ci., v. 59 , no. 3 , pp. $213-218$.

Janvier, P., and Melo, J. H. G., 1988, Acanthodian fish remains from the Upper Silurian or Lower Devonian of the Amazon Basin, Brazil: Paleontology, v. 31, pp. 771-777.

Janvier, P., and Melo, J. H. G., 1992, New acanthodian and chondrichthyan remains from the Lower and Middle Devonian of Brazil. Neues Jahrbuch f. Geol. u. Paleont., Monasthefte 4, pp. 193-206.

Katzer, F., 1897a, Das Amazonas-Devon und seine Beziehungen zu den anderen Devongebieten der Erde: Sitzungsberichte der königlichen böhmischen Gesellschaft der Wissenschaften, Mathematisch-naturwissenschaftliche Classe, v. 46, pp. 1-50.

Katzer, F., 1897b, A fauna devonica do rio Maecurú e as suas relações com a fauna de outros terrenos devonicos do globo: Boletim do Museu Paraense de Historia. Natural e Ethnographia, v. 2 , no. 2, pp. 204-246.

Kegel, W., 1953, Contribuição para o estudo do Devoniano da bacia do Parnaíba: Boletim Divisão de Geologia e Mineralogia, no. 141, pp. 1-48.

Kegel, W., 1957, Das Parnaiba-Becken: Geologische Rundschau, v. 45, no. 30 , pp. 522-540.

Kellner, A. W. A., 1987, Ocorrência de um novo crocodiliano no Cretáceo Inferior da bacia do Araripe, Nordeste do Brasil: An. Acad. Bras. Ci., v. 59 , no. 3, pp. 219-232.

Kellner, A. W. A., 1989, A new edentate pterosaur of the Lower Cretaceous from the Araripe Basin, Northeast Brazil: An. Acad. Bras. Ci., v. 61, no. 4, pp. 439-446.

Kellner, A. W. A., 1990, Os répteis voadores do Cretáceo brasileiro: Anuário do Instituto de GeociÍncias, CCMN, UFRJ, 1989, pp. 86-106.

Kellner, A. W. A., 1994, Comments on the paleobiogeography of Cretaceous archosaurs during the opening of the South Atlantic Ocean: Acta Geol. Leopol., v. 39, no. 2, pp. 615-625. 
Kellner, A. W. A., 1996a, Fossilized theropod soft tissue: Nature, v. 379, p. 32.

Kellner, A. W. A., 1996b, Remarks on Brazilian dinosaurs: Mem. Queensl. Mus., v. 39, no. 3, pp. 611-626.

Kellner, A. W. A., 1996c, Description of new material of Tapejaridae and Anhangueridae (Pterosauria, Pterodactyloidea) and discussion of pterosaur phylogeny: New York, Columbia University, 347 pp. (PhD Thesis, publ. Univ. Microfilms International, Ann Arbour, 1997.)

Kellner, A. W. A., 1996d, Reinterpretation of a remarkably well preserved pterosaur soft tissue from the Early Cretaceous of Brazil: Journal of Vertebrate Paleontology, v. 16, no. 4, pp. 718-722.

Kellner, A. W. A., 1998, Panorama e perspectiva do estudo de répteis fósseis no Brasil: An. Acad. Bras. Ciĺnc., v. 70, no. 3, pp. 647-676.

Kellner, A. W. A., and Campos, D.A., 1996, First Early Cretaceous theropod dinosaur from Brazil: N. J. Geol. Paläont., Abh., v. 199, no. 2, pp. 151166.

Kellner, A. W. A., and Campos, D. A., 1998, Archosaur soft tissue from the Cretaceous of the Araripe Basin, Northeastern Brazil: Boletim do Museu Nacional, Geologia, n. 42, pp. 1-22.

Kellner, A. W. A., Campos, D. A., Azevedo, S. A. K, and Carvalho, L. B., 1998, Theropod dinosaur eggs from the continental Upper Cretaceous of Minas Gerais: Jour. Vert. Paleont., v. 18, suppl. to 3, p. 55A.

Kellner, A. W. A., Campos, D. A., and Price, L. I., 1995, New material of Sphagesaurus (Sphagesauridae, Crocodilia) from the Late Cretaceous of Brazil: 14th Congresso Brasileiro de Paleontologia, Uberaba, 1995, Atas, pp. 70-71.

Kellner, A. W. A., Maisey, J. G., and Campos, D. A., 1994a, Fossil down feather from the Lower Cretaceous of Brazil: Paleontology, v. 37, no. 3, pp. 489-492.

Kellner, A. W. A., Maisey, J. G., and Evander, R. L., 1994b, Ein besonderes Fossil: die Henkersmahlzeit eines Fisches aus der Kreide: Paläont. Z., v. 68 , no. $1 / 2$, pp. $1-3$.

Kellner, A. W. A., Schwanke, C., and Campos, D. A., 1999, O Brasil no tempo dos dinossauros: Rio de Janeiro, Museu Nacional, $60 \mathrm{pp}$.

Langer, M. C., and Schultz, C. L., 1997, Comments on the phylogeny of the Rhynchosauria (Reptilia - Diapsida): 15th Congresso Brasileiro de Paleontologia, São Pedro, 1997, Boletim de resumos, p. 97.

Lavina, E. L., 1983, Procolophon pricei, sp. n. um novo procolofonídeo do Triássico do Rio Grande do Sul: Iheringia, no. 2. pp. 51-78.

Lavina, E. L., Araújo-Barberena, D. C., and Azevedo, S. A., 1991, Tempestades de inverno e altas taxas de mortalidade de répteis mesossauros. Um exemplo a partir do afloramento Passo São Borja, RS: Pesquisas, v. 18, no. 1, pp. 64-70.

Lavina, E. L., Richter, M., and Malabarba, M. C. S. L., 1995, Relatório do $1^{\circ}$ Workshop de integração da Geologia e Paleontologia de Vertebrados no RS: Comun. Mus. Ci.Tecnol. UBEA/PUCRS, sér. Ci. Terra, v. 1, pp. 311.

Leonardi, G., 1981, Novo icnogênero de tetrápode mesozóico da formação Botucatu, Araraquara, SP: An. Acad. Bras. Ci., v. 53, no. 4, pp. 793-805.

Leonardi, G., 1983, Notopus petri nov. gen., nov. sp: une empreinte d'amphibien de Dévonien au Paraná (Brésil): Geobios, v. 16, no. 2, pp. 233-239.

Leonardi, G., 1994, Annotaded atlas of South America tetrapod footprints (Devonian to Holocene): Brasília, CPRM, $247 \mathrm{pp}$

Maisey, J. G., ed, 1991, Santana fossils; an illustrated atlas: Neptune, NJ, T. F. H., 459 pp.

Marshall, L. G., 1987, Systematics of Itaboraian (Middle Paleocene) age "opposum-like" marsupials from the limestone quarry at São José de Itaboraõ, Brasil, in M. Archer (ed.) Possums and Opossums: studies in evolution, pp. 91-160.

Martill, D. M., 1988, Preservation of fish in the Cretaceous Santana Formation of Brazil: Paleontology, v. 31, no. 1, pp. 1-18.

Martill, D. M., and Unwin, D., 1989, Exceptionally well preserved pterosaur wing membrane from the Cretaceous of Brazil: Nature, v. 340, pp. 138140 .

Martill, D. M., Cruickshank, A. R. I., Frey, E., Small, P. G., and Clarke, M., 1996, A new crested maniraptoran dinosaur from the Santana Formation (Lower Cretaceous) of Brazil: Jour. Geol. Soc. London, v. 153, pp. 5-8.

Martins Neto, R. G., and Kellner, A. W. A., 1988, Primeiro registro de pena na formação Santana (Cretáceo Inferior), bacia do Araripe, Nordeste do Brasil: An. Acad. Bras. Ci., v. 60, no. 1, pp. 61-68.

Mattar, L. C. B., 1987, Sobre Barberenasuchus brasiliensis gen. et sp. nov., do mesotriássico do Rio Grande do Sul, Brasil. I. Diagnoses genérica e específica: 10th Congresso Brasileiro de Paleontologia, Rio de Janeiro, 1987, Anais, v. 1, pp. 77-98.

Mendes, J. C., 1974, Pesquisas paleontológicas no Brasil: An. Acad. Bras. Ci., v. 46 , no. $3 / 4$, pp. $369-376$
Mendes, J.C., and Petri, S., 1971, Geologia do Brasil: Rio de Janeiro, Instituto Nacional do Livro, $207 \mathrm{pp}$.

Meylan, P. A., 1996, Skeletal morphology and relationships of the early Cretaceous side-necked turtle, Araripemys barretoi (Testudines: Pelomedusoides: Araripemydidae), from the Santana Formation of Brazil: Jour. Vert. Paleont., v. 16, no. 1, pp. 20-33.

Oelofsen, B., Araújo, D. C., 1983, Paleoecological implications of the distribution of mesosaurid reptiles in the Permian Irati Sea (Paraná Basin), South America: Rev. bras. Geoci., v. 13, no. 1, pp. 1-6.

Oelofsen, B., Araújo, D. C., 1987, Two mesosaurid reptiles (Mesosaurus tenuidens and Stereosternum tumidum) in Permian Gondwana of Southern Africa and South America: Jour. Sci., v. 83, no. 6, pp. 370-372.

Petri, S., and Fúlfaro, V.J., 1988, Geologia do Brasil: São Paulo, T. A. Queiroz, $631 \mathrm{pp}$.

Pons, D., Berthou, P. Y., and Campos, D. A., 1990, Quelques observations sur la palynologie de l'Aptien Supérieur el de l'Albien du bassin d'Araripe (N.E. du Brésil): 1st Simpósio sobre a Bacia do Araripe e Bacias Interiores do Nordeste, Crato, 1988, Atas, pp. 241-252.

Ponte, F. C. and Ponte Filho, F. C., 1996, Evolução tectônica e classificação da Bacia do Araripe, Boletim 4 Simp. Sobre Cretáceo do Brasil, pp. 123133.

Powell, J. E., 1987, Morfologia del esqueleto axial de los dinosaurios titanosáuridos (Saurischia, Sauropoda) del estado de Minas Gerais, Brasil: 10th Congresso Brasileiro de Paleontologia, 1987, Anais, v. 1, pp. $155-171$.

Price, L. I., 1945, A new reptil from the Cretaceous of Brazil: Notas prelim. Est. Serv. Geol. Mineral., no. 25, pp. 1-8.

Price, L. I., 1947, Um procolofonídeo do Triássico do Rio Grande do Sul: Bol. Div. Geol. Mineral., no. 122, pp. 1-27.

Price, L. I., 1948, Um anfibio labirintodonte da formação Pedra de Fogo, estado do Maranhão: Bol. Div. Geol. Mineral., no. 124, pp. 1-32.

Price, L. I., 1950, On a new crocodilian, Sphagesaurus, from the Cretaceous of the State of São Paulo, Brazil: An. Acad. Bras. Ci., v. 22, no. 1, pp. 7785

Price, L. I., 1951, Um ovo de dinossaurio na formação Bauru do Cretáceo do estado de Minas Gerais: Not. prelim. Est. Div. Geol. Mineral., v. 53, pp. $1-7$.

Price, L. I., 1953a, Os quelônios da formação Baurú, Cretáceo terrestre do Brasil meridional: Bol. Div. Geol. Mineral., no. 147, pp. 1-34.

Price, L. I., 1953b, Restos de mosassaurios de Pernambuco e considerações sôbre a presença destes répteis na bacia Amazônica do Brasil: Notas prelim. Est. Div. Geol. Mineral., no. 58, pp. 1-15.

Price, L. I., 1953c, A presença de pterosauria no Cretáceo Superior do estado da Paraíba: Notas prelim. Est. Div. Geol. Mineral., no. 71, pp. 1-10.

Price, L. I., 1957, A presença de Globidens no Cretáceo Superior do Brasil: Bol. Div. Geol. Mineral., no. 169, pp. 1-24.

Price, L. I., 1959, Sôbre um crocodilõdeo notossúquio do Cretácico brasileiro: Bol. Div. Geol. Mineral., no. 188, pp. 1-55.

Price, L. I., 1964, Sôbre a mandõbula de um gigantesco crocodilídeo extinto do alto rio Juruá, estado do Acre: An. Acad. Bras. Ci., v. 36, no. 1, pp. 5966.

Price, L. I., 1967, Sôbre o crânio de um grande crocodilídeo extinto do alto rio Juruá, estado do Acre: Simpósio sôbre a Biota Amazônica, Belém, 1966, Atas, v. 1, pp. 359-371.

Price, L. I., 1971, A presença de pterosauria no Cretáceo Inferior da chapada do Araripe, Brasil: An. Acad. Bras. Ci., v. 43, supl., pp. 452-461.

Price, L. I., 1973, Quelônio Amphichelydia no Cretáceo Inferior do Nordeste do Brasil: Rev. bras. Geoci., v. 3, no. 2, pp.84-96.

Ramos, J. R. A., 1985, O cenário paleontológico brasileiro e seus atores, in Campos, D. A., Ferreira, C. S., Brito, I. M., and Viana, C. F., eds, Colet, nea de trabalhos paleontológicos: Brasõlia, DNPM, pp. 13-16.

Richter, M., 1985, Situação da pesquisa paleoictiológica no Paleozóico Brasileiro, in Campos, D. A., Ferreira, C. S., Brito, I. M., and Viana, C. F., eds, Coletânea de trabalhos paleontológicos: Brasília, DNPM, pp. $105-110$.

Santos, R. S., 1961, Peixes fósseis do Devoniano Inferior de Picos, estado do Piauí: An. Acad. Bras. Ci., v. 33 , no. 3/4, p. xxxii.

Santos, R. S., and Valença, J. G., 1968, A formação Santana e a sua paleoictiofauna: An. Acad. Bras. Ci., v. 40, no. 3, pp. 339-360.

Sayão, J. M., and Kellner, A. W. A., 1998, Pterosaur wing with soft tissue from the Crato Member (Aptian-Albian), Santana Formation, Brazil: Jour. Vert. Paleont., v. 15, suppl. to 3, p. 75A.

Schobbenhaus, C., Campos, D. A., Derze, G. R., and Asmus, H. E., 1984 Geologia do Brasil: Brasõlia, D.N.P.M., Brasília, 501 pp.

Schwanke, C., 1995, A utilização de dicinodontes em correlações biostratigráficas no Meso e Neotriássico: Comunicaçıes do Museu de 
Ciências e Tecnologia, UBEA/PUCRS, Série Ciĺncias da Terra, v. 1, pp. 57-62.

Schwanke, C., 1998, Estabelecimento de rotas de dispersão mediante o estudo da herbivoria em dicinodontes: Porto Alegre, Universidade Federal do Rio Grande do Sul, 394 pp. (Doctorate Thesis, unpublished.)

Schwanke, C., and Kellner, A. W. A., 1999, Sobre o primeiro registro de Synapsida no Triássico basal do Brasil: 16th Congresso Brasileiro de Paleontologia, Crato, 1999, Boletim de resumos, p. 101.

Silva, S. D., 1997, Novos achados de vertebrados fósseis na formação Sanga do Cabral: 15th Congresso Brasileiro de Paleontologia, São Pedro, 1997, Boletim de resumos, p. 82.

Soares, P. C., Landim, P. M. B., Fulfaro, V. J., and Sobreito Neto, A. F., 1980, Ensaio de caracterização estratigráfica do Cretáceo no estado de São Paulo: grupo Bauru: Rev. bras. Geoci., v. 10, no. 3, pp. 177-185.

Soria, M., and Alvarenga, H., 1989, Nuevos restos de mamíferos de la cuenca de Taubaté, estado de São Paulo, Brasil: An. Acad. Bras. Ci., v. 61 , no. 2, pp. $157-175$

Souza, J. J., 1984, O grupo Bauru na porção mais setentrional da bacia sedimentar do Paraná: 33rd Congresso Brasileiro de Geologia, 1984, Anais, v. 2, pp. 944-957.

Spix, J. B. and Martius, C. F. P., 1823-1831, Reise in Brasilien, 3v. and atlas. Munich.

Suárez, J. M., 1969, Um quelônio da formação Bauru: Bol. Dep. Geogr. Facul. Filos., Ci. Let. de Presidente Prudente, v. 2, pp. 35-54.

Travassos, H. and Santos, R. S. S., 1955, Caracídeos fósseis bacia do Paraíba: An. Acad. Bras. Ci., v. 27 , no. 3, pp. 297-322, VII figs.

Vidal, N., 1946, Contribuição ao conhecimento da Paleontologia do Nordeste brasileiro. Notõcia sobre a descoberta de vertebrados pleistocênicos no município de Pesqueira, em Pernambuco: Boletim do Museu Nacional, Nova Série, Geologia, no. 6, pp. 1-15.

Vidal, N., 1955, Estudo descritivo e comparativo de Macrauchenia patachonica Owen de Pernambuco: Boletim do Museu Nacional, Nova Série, Geologia , no. 21, pp. 1-39.

Vidal, N., 1959, Um Toxodon no Pleistoceno de Pernambuco: Boletim do Museu Nacional, Nova Série, Geologia, no. 30, pp. 1-17.

Wellnhofer, P., 1987, New crested pterosaurs from the Lower Cretaceous of Brazil: Mitt. Bayer. Staatsslg. Paläont. hist. Geol., v. 27, pp. 175-186.

Wellnhofer, P., 1991, Weitere Pterosaurierfunde aus der Santana Formation (Apt) der Chapada do Araripe, Brasilien, Palaeontographica, ser. A, v. 215, pp. 43-101.
Alexander Wilhelm Armin Kellner was born in Vaduz, Liechtenstein in 1961. He graduated in Geology at Universidade Federal do Rio de Janeiro (UFRJ) and got his Ph.D. in Geological Sciences at Columbia University (New York), in a joint program with the American Museum of Natural History (AMNH). He works at the National Museum (MN/UFRJ) in Rio de Janeiro, where he is the chairman of the Department of Geology and Paleontology. Kellner studies several aspects (e.g., systematics, taphonomy) of fossil reptiles having made important contributions to the understanding of Mesozoic life forms. He is Correspondent Member of the Brazilian Academy of Sciences and Research Associate of the AMNH.

Diogenes de Almeida Campos, geologist, started in 1968 at the Departa mento Nacional de Produção Mineral (DNPM). Presently he his Chief of the DNPM District in Rio de Janeiro, where he is also the responsible for the Earth Science Museum. He published over 100 publications concerning Paleontology and Estratigraphy. Member of the Brazilian Academy of Sciences and Latin American Academy of Sciences, he is also the chairman of the Brazilian Committee of the $I G C P$, member of the Brazilian Committee of the IGBP and of the Organizing Committee of the 31st IGC, Correspondent Member of the Muséum national d'Histoire Naturelle (Paris) and Research Associate of the American Museum of Natural History (New York).
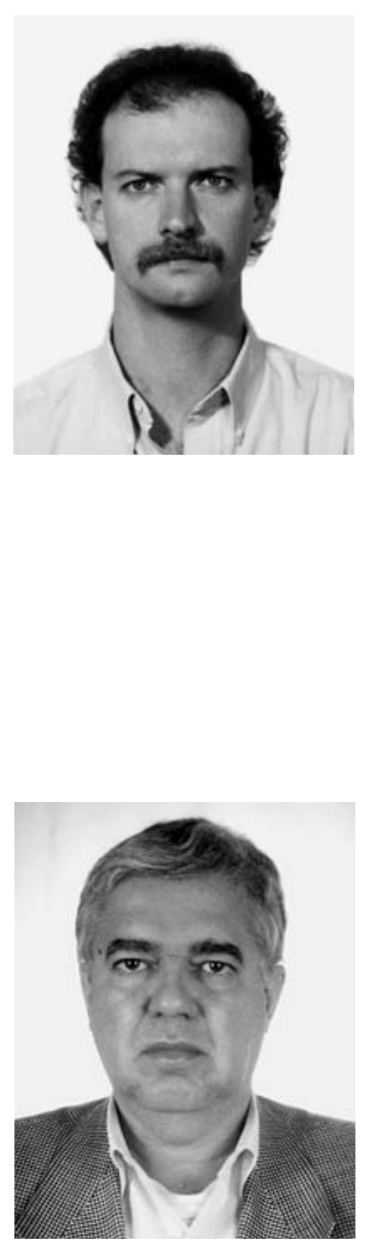